
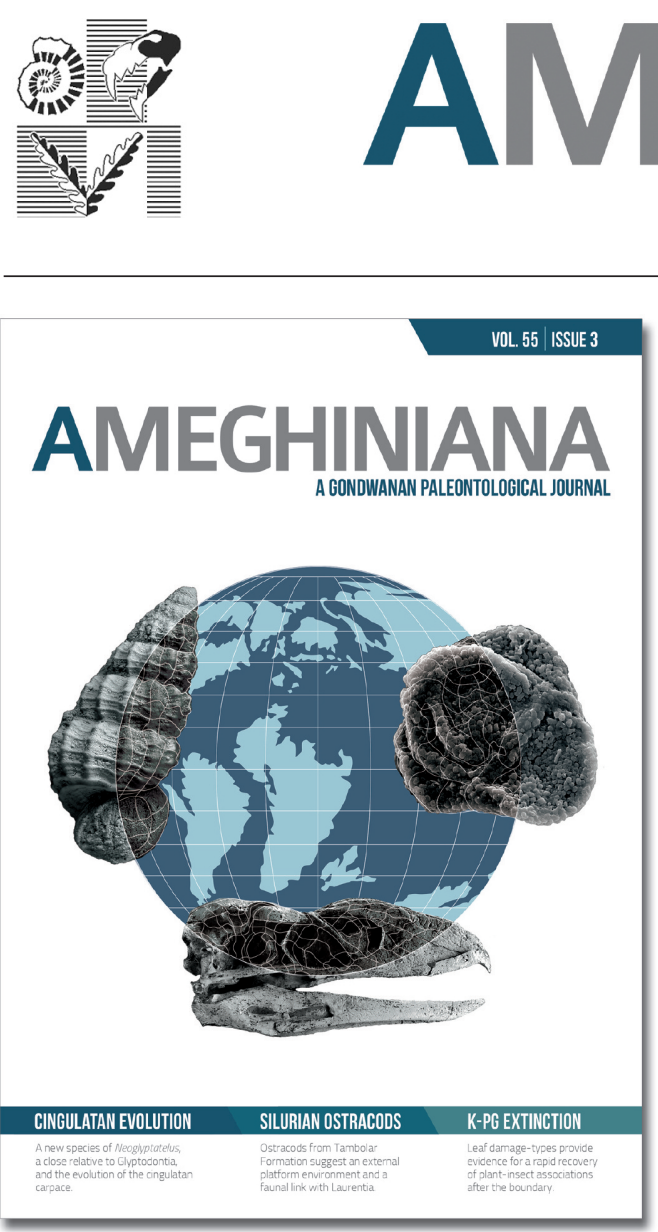

\title{
A NEW SPECIES OF NEOGLYPTATELUS (MAMMALIA, XENARTHRA, CINGULATA) FROM THE LATE MIOCENE OF URUGUAY PROVIDES NEW INSIGHTS ON THE EVOLUTION OF THE DORSAL ARMOR IN CINGULATES
}

\author{
JUAN C. FERNICOLA ${ }^{1,2}$ \\ ANDRÉS RINDERKNECHT ${ }^{3}$ \\ WASHINGTON JONES ${ }^{3}$ \\ SERGIO F. VIZCAÍNO ${ }^{4}$ \\ KLEBERSON PORPINO ${ }^{5}$
}

\begin{abstract}
${ }^{1}$ Rivadavia". Av. Ángel Gallardo 470 1405DJR, Buenos Aires, Argentina. (CONICET).
²Departamento de Ciencias Básicas, Departamento de Ciencias Básicas, Universidad Nacional de Luján, Ruta 5 y Avenida Constitución, 6700, Luján, Buenos Aires, Argentina.

${ }^{3}$ Museo Nacional de Historia Natural, 25 de Mayo 582 C.P. 11000. Montevideo, Uruguay.

4División Paleontología Vertebrados, Unidades de investigación Anexo Museo, Facultad de Ciencias Naturales y Museo Calle 60 y 122,1900 La Plata, Argenitna (CONICET).

${ }^{5}$ Departamento de Ciências Biológicas, Universidade do Estado do Rio Grande do Norte, Rua Antônio Campos s/n, Mossoró, 59610-090, Rio Grande do Norte, Brazil.
\end{abstract}

Submitted: August 24 ${ }^{\text {th }}, 2017$ - Accepted: December 2nd 2017 - Published online: December 19, 2017

To cite this article: Juan C. Fernicola, Andrés Rinderknecht, Washington Jones, Sergio F. Vizcaíno, and Kleberson Porpino (2018). A new species of Neoglyptatelus (Mammalia, Xenarthra, Cingulata) from the late Miocene of Uruguay provides new insights on the evolution of the dorsal armor in cingulates. Ameghiniana 55: $233-252$.

To link to this article: http://dx.doi.org/10.5710/AMGH.02.12.2017.3150

PLEASE SCROLL DOWN FOR ARTICLE

Also appearing in this issue:

\section{CINGULATAN EVOLUTION}

A new species of Neoglyptatelus, a close relative to Glyptodontia, and the evolution of the cingulatan carpace.

\section{SILURIAN OSTRACODS}

Ostracods from Tambolar Formation suggest an external platform environment and a faunal link with Laurentia.

\section{K-PG EXTINCTION}

Leaf damage-types provide evidence for a rapid recovery of plant-insect associations after the boundary. 


\title{
A NEW SPECIES OF NEOGLYPTATELUS (MAMMALIA, XENARTHRA, CINGULATA) FROM THE LATE MIOCENE OF URUGUAY PROVIDES NEW INSIGHTS ON THE EVOLUTION OF THE DORSAL ARMOR IN CINGULATES
}

\author{
JUAN C. FERNICOLA ${ }^{1,2}$, ANDRÉS RINDERKNECHT ${ }^{3}$, WASHINGTON JONES ${ }^{3}$, SERGIO F. VIZCAIINO ${ }^{4}$, AND KLEBERSON PORPINO5
}

1Sección Paleontología de Vertebrados, Museo Argentino de Ciencias Naturales "Bernardino Rivadavia". Av. Ángel Gallardo 470 1405DJR, Buenos Aires, Argentina. (CONICET).jctano@yahoo.com

²Departamento de Ciencias Básicas, Departamento de Ciencias Básicas, Universidad Nacional de Luján, Ruta 5 y Avenida Constitución, 6700 , Luján, Buenos Aires, Argentina.

${ }_{3}^{3}$ Museo Nacional de Historia Natural, 25 de Mayo 582 C.P. 11000. Montevideo, Uruguay.apaleorinder@yahoo.com;wawijo@yahoo.com.ar

4División Paleontología Vertebrados, Unidades de investigación Anexo Museo, Facultad de Ciencias Naturales y Museo Calle 60 y 122,1900 La Plata, Argenitna (CONICET).vizcaino@museo.fcnym.unlp.edu.ar

${ }^{5}$ Departamento de Ciências Biológicas, Universidade do Estado do Rio Grande do Norte, Rua Antônio Campos s/n, Mossoró, 59610-090, Rio Grande do Norte, Brazil. kleporpino@yahoo.com.br

\begin{abstract}
The genus Neoglyptatelus Carlini, Vizcaíno and Scillato-Yané has been considered a member of Glyptatelinae, a group encompassing the purportedly basal-most glyptodonts. It is up to now represented by two species from Colombia: Neoglyptatelus originalis Carlini, Vizcaíno and Scillato-Yané, from the middle Miocene (a carapace fragment, isolated osteoderms and postcranial bones), and Neoglyptatelus sincelejanus Villarroel and Clavijo, from the middle or late Miocene (a partial carapace and a caudal armor). More scarce material assigned to this genus was recovered from the late Miocene of Uruguay and Brazil. In this article, we describe a new species, Neog/yptatelus uruguayensis, from the late Miocene Camacho Formation, Uruguay, based on an almost complete carapace and several postcranial bones. We conducted a phylogenetic analysis based on 167 morphological characters (23 new ones and 144 from previous analysis) scored for 19 taxa, encompassing some of the best known glyptodontid genera, one pampathere and four armadillos (including the enigmatic genus Pachyarmatherium Downing and White). In the most parsimonious tree that was obtained, Neoglyptatelus forms a clade with Pachyarmatherium (Pachyarmatheriidae), which is the sister group of the glyptodonts + pampatheres clade; consequently, it is not a glyptodont, as previously believed. This result, together with the known stratigraphic and geographic distribution of Neog/yptatelus and Pachyarmatherium, suggests that this new cingulate clade originated in South America and that Pachyarmatherium reached North America during the Plio-Pleistocene. The carapace of Neog/yptatelus and Pachyarmatherium comprises pelvic and scapular shields overlapping each other without separate intervening transverse mobile bands, an arrangement that differentiates both genera from the remaining cingulates.
\end{abstract}

Key words. Carapace. Movement. Pachyarmatheriidae. Glyptatelinae. Phylogeny.

Resumen.UNA NUEVA ESPECIE DE NEOGLYPTATELUS (MAMMALIA, XENARTHRA, CINGULATA) DEL MIOCENO TARDÍO DE URUGUAY PROPORCIONA NUEVAS PERSPECTIVAS SOBRE LA EVOLUCIÓN DEL CAPARAZÓN DORSAL EN LOS CINGULADOS. El género Neoglyptatelus Carlini, Vizcaíno and Scillato-Yané ha sido considerado un miembro de los Glyptatelinae, un grupo que supuestamente incluye a los gliptodontes basales. Actualmente, está representado por dos especies halladas en Colombia: Neoglyptatelus originalis Carlini, Vizcaíno and Scillato-Yané, del Mioceno medio (fragmento de caparazón, osteodermos aislados y elementos postcraneanos) y Neog/yptatelus sincelejanus Villarroel y Clavijo del Mioceno medio o tardío (parte de un caparazón y coraza caudal). Osteodermos aislados asignados a este género fueron recuperados en el Mioceno tardío de Uruguay y Brasil. En este trabajo, nosotros describimos una nueva especie, Neoglyptatelus uruguayensis, del Mioceno tardío de la Formación Camacho, Uruguay, a base de una coraza casi completa y distintos elementos postcraneanos. Nuestro estudio filogenético se sustenta en 167 caracteres óseos (23 nuevos y 144 utilizados previamente) relevados en 19 taxones, que incluyen los géneros de gliptodontes mejor conocidos, un pampaterio y cuatro armadillos, incluyendo Pachyarmatherium Downing y White. En el árbol más parsimonioso obtenido Neoglyptatelus forma con Pachyarmatherium un clado (Pachyarmatheriidae) hermano del grupo formado por pampaterios + gliptodontes, por lo cual no es un gliptodonte como se sostenía previamente. Este resultado, junto al conocimiento estratigráfico y geográfico de Neog/yptatelus y Pachyarmatherium, sugiere que los Pachyarmatheriidae se habrían originado en América del Sur y que durante el Plio-Pleistoceno Pachyarmatherium arribó a América del Norte. El caparazón de Neoglyptatelus y Pachyarmatherium contiene un escudo escapular y otro pélvico que solapan directamente entre sí, sin mediar bandas movibles transversas; este arreglo morfológico es único entre los cingulados.

Palabras clave. Caparazón. Movimiento. Pachyarmatheriidae. Glyptatelinae. Filogenia. 
THE genus Neog/yptatelus and its type species Neoglyptatelus originalis were established on a small fragment of dorsal carapace, isolated osteoderms and various postcranial bones (Carlini et al., 1997) from the middle Miocene of the La Venta Formation in Colombia (Madden et al., 1997). A small maxilla and mandible were included, with doubt, in the hypodigm because there was no clear association between these specimens and the diagnostic carapace material; unfortunately, these specimens were not described (Carlini et al., 1997).

Vizcaíno et al. (2003) assigned several isolated osteoderms from the late Miocene of Uruguay to this genus. Later, Villarroel and Clavijo (2005) founded a new species, Neoglyptatelus sincelejanus, from the middle or late Miocene of Colombia, on a partial carapace and a fragment of caudal armor. The genus was also recorded in the late Miocene age from Acre, Brazil (Cozzuol, 2006).

Neoglyptatelus was assigned by Carlini et al. (1997) to the Glyptatelinae, a poorly defined group widely believed to include the basalmost glyptodonts (Hoffstetter, 1958). It was characterized by showing, on the external surface of the osteoderms, the main figure displaced towards the posterior edge and the presence of lobulated teeth, similar to those of other glyptodonts, but without central hard osteodentine crests. The type genus of Glyptatelinae is the poorly known Glyptatelus Ameghino, 1897, from the late Eocene to late Oligocene of Bolivia and Argentina (McKenna and Bell, 1997). According to Ameghino (1902), the type specimen (MACN-A 52-356) of Glyptatelus included osteoderms and teeth. However, the teeth were consistently reassigned to Pseudoglyptodon Engelmann, 1987, an unusual Folivora (sloth) with glyptodont-like teeth (Wyss et al., 1994; McKenna et al., 2006). Other taxa recognized by McKenna and Bell (1997) as belonging to Glyptatelinae are Clypeotherium Scillato-Yané, 1977, from the late Eocene to late Oligocene of Bolivia and Argentina; Lomaphorelus Ameghino, 1902, from the Eocene of Patagonia (considered nomen $d u$ bium by Vizcaíno et al., 2003); and the late Pliocene-late Pleistocene Pachyarmatherium Downing and White, 1995, from USA (Downing and White 1995), Brazil (Porpino et al., 2009), Perú, (Martinez et al., 2008; Martinez and Rincón, 2010), Uruguay (Bostelmann et al., 2008), and Venezuela (Rincón and White, 2007). Pachyarmatherium, which is quite similar to Neog/yptatelus, was recently positioned by Por- pino et al. (2009, 2010) out of glyptodonts, as the sister group of Pampatheriidae + Glyptodontia.

Considering the material so far described, the principal feature that Neoglyptatelus shares with the remaining Glyptatelinae is the posterior displacement of the main figure on the external surface of the carapace osteoderms. However, this feature is also present in the other glyptodonts, such as Parapropalaehoplophorus Croft et al., 2007 and Paraeucinepeltus González-Ruiz et al., 2011, and some portions of the carapace of Propalaehoplophorus Ameghino, 1887a. All this casts doubts on the assignment of Neoglyptatelus to the Glyptatelinae and on the validity of this subfamily.

Herein, we describe a new specimen belonging to a new species of Neog/yptatelus from the Miocene of Uruguay. The excellently preserved exoskeleton and some associated postcranial elements assignable to this taxon shed new light on the affinities of Neoglyptatelus and on the evolution of the pattern of carapace mobility among cingulates.

\section{GEOLOGICAL SETTING}

The fossil-bearing strata are located in southwestern Uruguay (San José Department; 34 34' S; 56 58' W) in exposures located on the coastal cliffs and littoral platform of Río de La Plata (Fig. 1). There, the lithostratigraphic units recognized from the base to the top are the Camacho (late Miocene), the Raigón (Pliocene and Pleistocene) and the Libertad (Pleistocene) Formations (Bossi and Navarro 1991; Tófalo et al., 2009). The first two units yield many vertebrate fossils, including a variety of cingulates, ground sloths, rodents and notoungulates. The remains hereby described were found in sediments of the Camacho Formation. This Formation is the representation, in Uruguay, of an extended, late Miocene, eustatic event regionally known as the Paranean transgression or Paranean Sea. In the San José Department, this includes facies related to the regressive phase characterized as estuarine and/or paralic environments. The fossil assemblage of the unit comprises terrestrial and fresh-water vertebrates in association with marine invertebrates and ichnofossils (Ubilla et al., 1990; Perea et al., 1996; Sprechmann et al., 2000; Perea 2005). The sediments of the Camacho Formation are formed by greenishgrey friable and medium compressed pelite that becomes greenish-brownish toward the top of the formation. The 


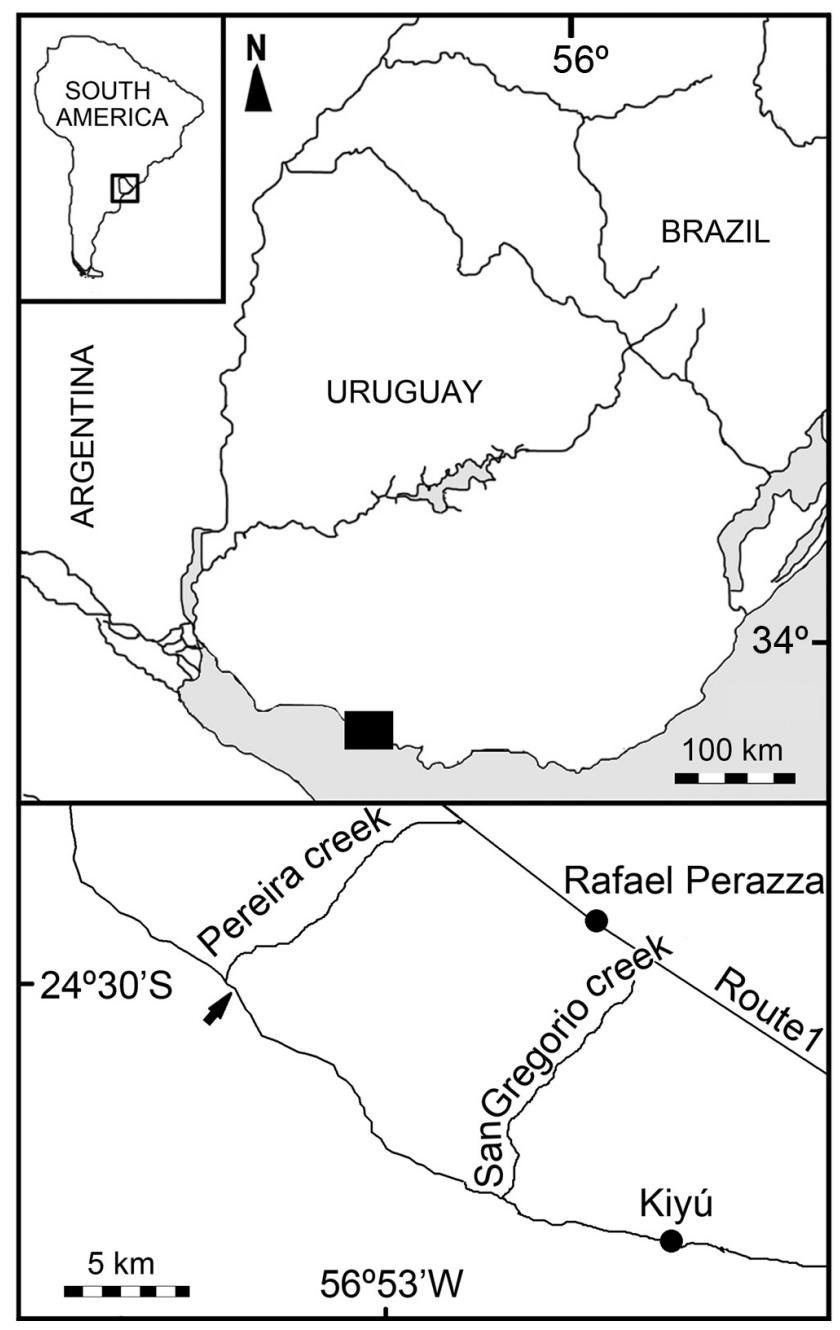

Figure 1. Map of the region where the holotype of Neog/yptatelus uruguayensis was collected. The arrow indicates the precise geographic location where MNHN 1642 was found.

mammalian fossil assemblage includes marsupial carnivores, xenarthrans, notoungulates, litopterns, hystricognath rodents and cetaceans, thus showing affinities with the late Miocene Chasicoan and Huayquerian Ages/Stages of Argentina, especially with the one informally known as the "Mesopotamiense" (formerly considered a Huayquerian age local fossil fauna) of the Entre Ríos Province (Bostelmann and Rinderknecht, 2010; Brandoni 2013; Perea et al., 1994; Perea 2005; Perea et al., 2013; Rinderknecht et al., 2011; Vizcaíno et al., 2003). ${ }^{40} \mathrm{Sr} /{ }^{39} \mathrm{Sr}$ dated levels of the Paraná Formation and its southern correlative, the Puerto Madryn Formation, render a late Miocene 9.5 Ma - $10 \mathrm{Ma}$ (Tortonian) age for the top of the Paranean Sea in Argentina (Scasso et al., 2001).

\section{MATERIAL AND METHODS}

A cladistic analysis was conducted using TNT 1.5 (Goloboff and Catalano, 2016) to assess the phylogenetic relationships of Neoglyptatelus within Glyptodontia (sensu Fernicola, 2008), taking into consideration that this taxon had been previously assigned to this group (Carlini et al., 1997; McKenna and Bell, 1997). The data matrix includes 19 taxa and 167 morphological characters (Supplementary appendix 1, 2, and 3). These latter correspond to 84 craniodental characters from Fernicola (2008), three of which were originally proposed by Gaudin and Wible (2006); 83 postcranial characters, 60 of which based on three previous studies (Porpino et al., 2009, 2010; Fernicola and Porpino, 2012) on the systematic of glyptodonts; and 23 new characters (see Appendix I for descriptions and sources of each). The postcranial characters were derived and scored via the direct observation of the specimens and the descriptions and figures in the literature. Forty-eight multistate characters were treated as ordered in the analysis based on numerical and structural morphoclines following the 'method of intermediates' (Wilkinson, 1992). All the characters were equally weighted. From the 19 taxa included in this analysis, 14 correspond to the ingroup: Neoglyptatelus (Glyptatelidae); Propalaehoplophorus and Eucinepeltus Ameghino, 1891 (Propalaehophoridae); Panochthus Burmeister, 1866, Neosclerocalyptus Paula Couto, 1957 and Hoplophorus Lund, 1839 (Panochthidae); Plohophorus Ameghino, 1887b, Doedicurus Burmeister, 1874 and Glyptodon Owen, 1839 (Glyptodontidae); Pseudoplohophorus Engelmann, 1987, Stromaphorus Castellanos, 1926, Hoplophractus Cabrera, 1939 and Eosclerocalyptus Ameghino, 1919 (Glyptodontoinei); and Urotherium Castellanos, 1926 (Glyptodontoidea). Recently, Zurita et al. (2017) synonimized Urotherium antiquum Ameghino, 1888 with Plohophorus figuratus Ameghino, 1887b based, among others, on the study of MACN-A 229-231 and MLP 16-153 (holotype), specimens which were assigned to both taxa, respectively. However, both specimens had been included in previous phylogenetic studies (Fernicola, 2008; Porpino et al., 2010; Fernicola and Porpino, 2012) and the taxa that these specimens represent do not form a natural group. Consequently, this synonymy proposal has not been considered in this study. The outgroups include four dasypodids (Eutatus Gervais, 1867, Dasypus Linnaeus, 1758, Pachyarmatherium and Euphractus 
Wagler, 1830) and one pampathere (Pampatherium Gervais and Ameghino, 1880).

With respect to the taxonomy of Pachyarmatherium, we follow Oliveira et al. (2013), who claim that an exhaustive review of the species $P$. tenebris and $P$. brasiliensis is necessary before definitively accepting the synonymy proposed by Martinez and Rincón (2010) and Valerio and Laurito (2011). As noted by Oliveira et al. (2013), the type specimens of both species show some differences, as evidenced by a superficial comparison of their respective diagnoses; yet, the available samples for South American species of Pachyarmatherium are small so the discovery of more complete and abundant material would be crucial for a better assessment of their potential synonymy.

All measurements were taken to the nearest $0.1 \mathrm{~mm}$ using a digital calliper. Unless otherwise indicated, we use the term osteoderm to denote the bony components of the carapace, and the term scale for the keratinous portion of such components (Krmpotic et al., 2009; Vickaryous and Hall, 2006; Hill, 2006). With respect to the ornamentation pattern, we follow Fernicola and Porpino (2012).

Institutional abbreviations. AMNH, American Museum of Natural History, New York, USA; FC-DPV, Colección de Vertebrados Fósiles, Facultad de Ciencias, Universidad de la República, Montevideo, Uruguay; MACN-A, Colección Ameghino, Museo Argentino de Ciencias Naturales "Bernardino Rivadavia", Ciudad Autónoma de Buenos Aires, Argentina; MACN-Ma, Colección Mastozoología, Museo Argentino de Ciencias Naturales "Bernardino Rivadavia," Ciudad Autónoma de Buenos Aires, Argentina; MACN-Pv, Colección Paleontología de Vertebrados, Museo Argentino de Ciencias Naturales "Bernardino Rivadavia," Ciudad Autónoma de Buenos Aires, Argentina; MCC, Museu Câmara Cascudo, Natal/RN, Brazil; MNHN, Museo Nacional de Historia Natural, Montevideo, Uruguay, MPEF-PV, Colección Paleontología de Vertebrados, Museo Paleontológico Egidio Feruglio, Trelew, Chubut, Argentina; MLP, Museo de La Plata, La Plata, Argentina; PV UNS, Colección Paleontología de Vertebrados, Universidad Nacional del Sur, Bahía Blanca, Buenos Aires, Argentina.

\section{SYSTEMATIC PALEONTOLOGY}

Order CINGULATA Illiger, 1811

\section{Family PACHYARMATHERIIDAE new rank}

Type genus. Pachyarmatherium Downing and White, 1995. Diagnosis. The carapace of this group differs from that of the known remaining Cingulata in having scapular and pelvic shields articulated without intermediating mobile bands among them.

Geographic and temporal occurrence. In North America, from the late Pliocene to the Early Pleistocene of Florida and in the late Pliocene of South Carolina (Downing and White, 1995 and Hulbert, 2001); in Central America, in the late Blancan-early Irvingtonian of Costa Rica (Laurito et al., 2005, Laurito and Valerio 2012); in South America, in the Plio-Pleistocene of Venezuela (Rincón et al., 2009, Solórzano et al. 2015), in the late Pleistocene of Venezuela and Perú (Rincón and White, 2007; Martinez et al., 2008; Martinez and Rincón, 2010), in the middle-late? Miocene of Colombia (Madden et al., 1997), in the late Pleistocene to early Holocene of Brazil (Porpino et al., 2009; Oliveira et al., 2009), in the late Miocene of Brazil (Cozzuol (2006), and in the late Miocene (Vizcaíno et al., 2003) and the Quaternary of Uruguay (Bostelmann et al., 2008).

\section{Genus NEOGLYPTATELUS Carlini, Vizcaíno, and Scillato-Yané, 1997}

Type species. Neog/yptatelus originalis Carlini, Vizcaíno, and ScillatoYané, 1997

Emended diagnosis. The osteoderms of this genus differ from those of Pachyarmatherium in having narrow and shallow sulci (instead of wide and deep), and smaller foramina. They differ further from those of Pachyarmatherium in having each anterior caudal ring formed by two rows of osteoderms instead of three, and in having the articulation zone of the carapace formed by the two posteriormost transversal rows of the scapular shield and the two anteriormost transversal rows of the pelvic shield (instead of by single posteriormost and anteriormost transversal rows of the scapular and pelvic shields, respectively). It differs from Glyptatelus and Clypeotherium in the following features: it is smaller, its main figure is polygonal (instead of rounded). It differs further from Clypeotherium in having its external surface moderately wrinkled (instead of strongly wrinkled and punctuated). 
Geographic and temporal occurrence. Middle-late? Miocene of Colombia (Madden et al., 1997), and late Miocene (Vizcaíno et al., 2003) and Quaternary of Uruguay (Bostelmann et al., 2008), South America.

Neoglyptatelus uruguayensis sp. nov.

Figures 2.1-3, 3.1-6, 4.1-2, 5.1-2, 6.1-5

Derivation of name. uruguayensis; from Uruguay, to emphasize its geographic provenance.

Type material. MNHN 1642, partial skeleton including: the right portion of the pelvic shield; a nearly complete pectoral shield; tail armor with vertebrae; three thoracic vertebrae fused, complete right hindlimb, and proximal half of the left femur.

Referred Specimen. MNHN 1483, 45 complete and 12 broken isolated osteoderms belonging to the same individual. Geographic occurrence. Uruguay, San José Department, erosional surface of Puerto Arazatí Beach, 3 to $4 \mathrm{~km}$ east of El Sauce Creek (Fig. 1).

Stratigraphic occurrence. Camacho Formation, Uruguay, late Miocene age.

Diagnosis. The osteoderms of Neoglyptatelus uruguayensis differ from those of Neoglyptatelus originalis in having smaller foramina and narrower sulci. The species differs from Neoglyptatelus sincelejanus in having the osteoderms of the dorsal region of the pelvic and scapular shields with six or seven peripheral figures (instead of five as maximum) and a convex external surface (instead of a plane one).

Descriptions and comparisons. The long bones described below show fused epiphyses indicating that the studied specimen is an adult individual. Its carapace is somewhat transversally flattened so that its measurements can be somewhat overestimated although not as much as to prevent a reliable description of its shape.

Carapace. The carapace of Neoglyptatelus uruguayensis presents a convex profile with an approximate anteroposterior longitude of $550 \mathrm{~mm}$. The maximum height of approximately $300 \mathrm{~mm}$ is in the region where both the scapular and the pelvic shields articulate. The height in the anterior portion is of approximately $140 \mathrm{~mm}$ and, in the posterior portion, of approximately 120 mm (Fig. 2.1-2).

Scapular shield. In lateral view, the scapular shield is nearly rectangular. Its anterior border is slightly concave while the posterior one is slightly convex. They are approximately of 140 and $300 \mathrm{~mm}$ in height, respectively. The ventral border is straight whereas the dorsal border is slightly convex (Fig. 2.1-2). They both have an anteroposterior length of $350 \mathrm{~mm}$. The osteoderms in the dorsal and lateral region are mostly hexagonal; a few are pentagonal (Fig. 3. 4-5). A narrow band comprising nearly two transversal rows anteriorly positioned and four sagital rows lateroventrally positioned present rectangular to subpentagonal ostoderms. The largest osteoderms occur on the dorsal region. They have an average anteroposterior length of $15 \mathrm{~mm}$ and mediolateral length of $13 \mathrm{~mm}$. In contrast, the osteoderms of the lateral region are $12.5 \times 11 \mathrm{~mm}$ in average. This size pattern is inversely correlated with the thickness of the osteoderms. Thus, in the dorsal region, the average thickness is of $6.5 \mathrm{~mm}$ whereas, in the lateral region, the average is of $8.5 \mathrm{~mm}$. The figures in the external surface of the osteoderms are smooth and flat to slightly convex. The main and radial sulci are straight, narrow and shallow (in contrast with Pachyarmatherium). Small hair follicle pits are located at the intersection of the main and radial sulci. In the dorsal region, they range from three to four, or exceptionally five, whereas, in lateral region, they range from two to three, or exceptionally four. The main figure is hexagonal and displaced posteriorly, and occasionally reaches the posterior border. Excepting the two anteriormost transversal rows, which form the scapular portion of the articulation area of the carapace (see below), the variation in the number of peripheral figures has a concentric pattern: in most dorsal and lateral regions, nearly $85 \%$ of the osteoderms present six peripheral figures whereas the remaining 15\% bear five, or exceptionally four, peripheral figures. This large area is surrounded by a narrow zone formed by osteoderms bearing two to four peripheral figures. On the other hand, in the anteroventral section, the osteoderms lack clearly discernible peripheral or main figures (Fig. 3.5). In the anterior and ventral borders, the ostoderms have an irregular shape. The osteoderms of the ventral border are pentagonal with a convex free border and a straight dorsal border, and their external surface is somewhat rough and lacks figures. The osteoderms of the anterior border are not preserved.

Pelvic shield. In lateral view, the pelvic shield is trapezoid. Its dorsal and ventral borders are both convex and of $300 \mathrm{~mm}$ and $220 \mathrm{~mm}$ in anteriorposterior length, respectively (Fig. 

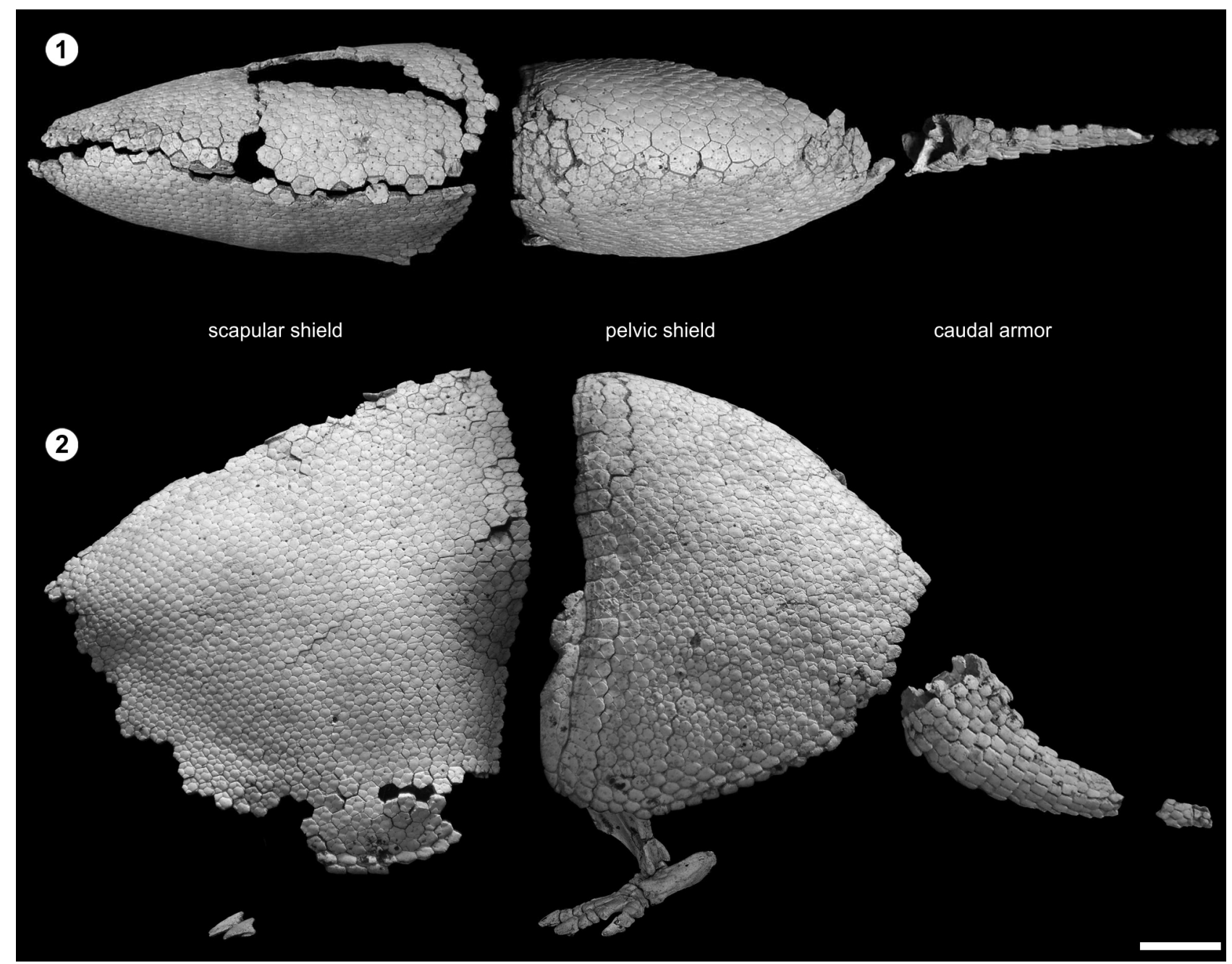

(3)

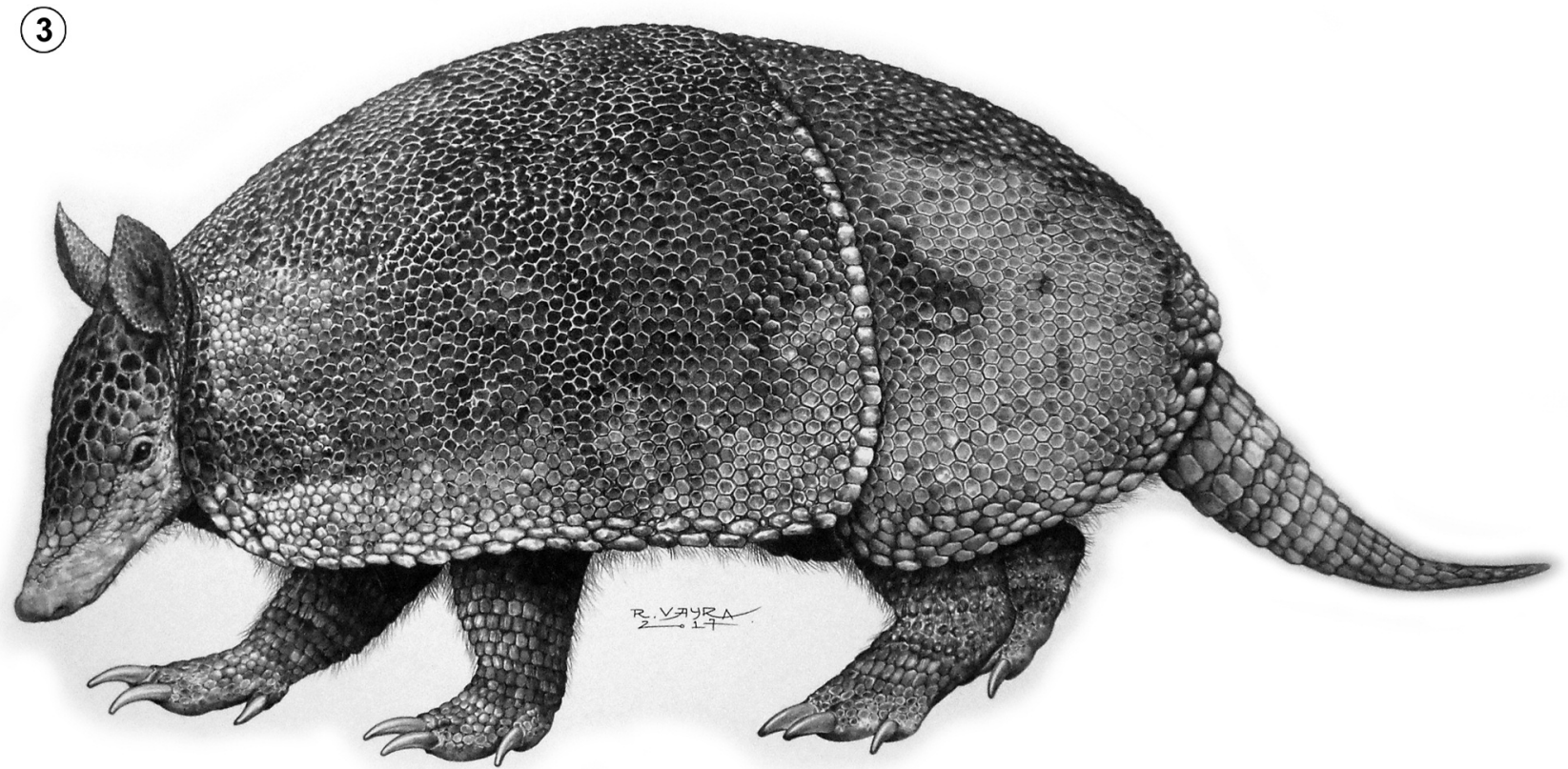

Figure 2. Complete specimen of the holotype of Neoglyptatelus uruguayensis (MHNM 1642). 1, dorsal view; 2, lateral view; 3, life reconstruction. Scale bar $=50 \mathrm{~mm}$. 
$2.1-2,3.1)$. The anterior border is slightly sigmoid while the posterior one is slightly concave. They are 280 and 150 $\mathrm{mm}$ high, respectively. Mostly, the osteoderms in the dorsal and lateral region are hexagonal, and a few ones are pentagonal. Excepting the osteoderms of the ventral border, the size of the osteoderms varies according to their topographic location along the pelvic shield. Thus, in the lateral region, the osteoderms have an average anteroposterior length of $11 \mathrm{~mm}$ and a mediolateral length of $8 \mathrm{~mm}$. In the dorsal region, the average anteroposterior length is of 12 , $5 \mathrm{~mm}$ and the average mediolateral length is of $8 \mathrm{~mm}$. Unfortunately, during preparation, it was necessary to apply a consolidant on the internal surface of the pelvic shield so that the thickness measurements were compromised. Except for a small area, in which they are strongly convex, the figures in the external surface of the osteoderms are smooth and mostly flat to slightly convex (Fig. 3.1-3). As in the scapular shield, the sulci that delineate these figures are straight, narrow and shallow. There are two to five small hair follicle pits at the intersection of the main and radial sulci. Laterally, these pits range from two to three, or exceptionally there is only one, whereas, in the dorsal region, they range from three to four, or exceptionally five. Posterior to the two transversal rows involved in the articulation area between the scapular and the pelvic shields (see below), the variation in size of the peripheral figures forming the pelvic shield follows a distribution pattern that is more complex than that of the scapular one. In the dorsal and the dorsolateral sections, nearly $90 \%$ of the osteoderms have six peripheral figures, whereas the remaining $10 \%$ have five to seven. Around this most central area, there is a band of osteoderms among which $90 \%$ present five peripheral figures whereas $10 \%$ show three to four. Finally, in the two ventralmost sagittal rows and the posteriormost row, peripheral figures range from one to two, or are entirely absent. The osteoderms of the ventral border are pentagonal with a convex ventral border and a straight dorsal one. Their external surface is rough and lacks figures. The few preserved osteoderms of the posterior border show a main figure with a very rough surface, and displaced posteriorly, occupying the posterior half of the osteoderm, the anterior half presents two to three peripheral figures.

Articulation area. This area is formed by the two posteriormost transverse rows of osteoderms of the scapular shield that overlap the first two anteriormost transverse rows of the pelvic shield. Regarding the scapular shield (Fig. 3.5-6), the penultimate row is almost complete whereas the last row is represented by three osteoderms only (Fig. 3.5). In internal view (Fig. 3.6), the posterior third of the osteoderms of the penultimate row and the anterior half of the osteoderms of the last row thin towards their contact zone and delineate a concave area (Fig. 3.6). The posterior half of the osteoderms of the last row is convex so that their anteroposterior axis shows a concavo-convex profile. With respect to the pelvic shield, only the left side of the first row is preserved; the second row is almost complete (Fig. 3.1-2). The preserved portion of the first row is formed by two elements: one is a single osteoderm of nearly $10 \mathrm{~mm}$ in dorsoventral length and $12 \mathrm{~mm}$ in anteroposterior length, which comprises part of the ventral border of the carapace; the other is a larger structure of $114 \mathrm{~mm}$ in dorsoventral length, which may have reached $150 \mathrm{~mm}$ taking into consideration that its dorsal portion is missing, and of nearly $20 \mathrm{~mm}$ in anteroposterior length. The external surface of this latter element is smooth and presents irregular sutures indicating that it was formed by the fusion of separate smaller osteoderms; it becomes thinner anteriorly. The posterior portion of this large element articulates with 12 osteoderms of the second transversal row of osteoderms. Dorsally, this second row presents nine additional osteoderms besides those articulating with the preserved portion of the large element of the first row. Among these, two osteoderms of more ventral position would have articulated with the missing portion of the large element while the remaining ones become slightly thinner anteriorly, indicating the absence of any anterior articulation area. Except for those closer to the ventral border, each preserved osteoderm of the second row of the pelvic shield presents a transversal depression on its anterior third that is contiguous with those in adjacent osteoderms, forming a sort of transverse canal (Fig. 3.2). Anterior to this canal, there is a convex small area with a smooth surface perforated by small foramina; posteriorly, there is a flat area presenting one main figure displaced posteriorly, as in other osteoderms of the scapular and pelvic shields, which are surrounded by three to five peripheral figures of varied size. All these figures are separated by narrow and shallow sulci. Small hair follicle pits are located at the intersection of these sulci. 
Caudal armor. The caudal armor (Fig. 2.1-2) is divided into an anterior and a posterior portion measuring approximately $160 \mathrm{~mm}$ and $110 \mathrm{~mm}$ in length, respectively. The anterior portion comprises six mobile rings of imbricating osteoderms. Each ring covers a caudal vertebra and is formed by two rows of osteoderms whose size decreases from the anteriormost rings to the posteriormost ones. The posterior portion is formed by imbricating osteoderms that, unlike those of the anterior portion, do not form discernible rings. All osteoderms in anterior and posterior portions present smooth external surfaces without any discernible figures.

Dorsal vertebrae. The preserved fragment of the vertebral column comprises three fused vertebrae, four free thoracic and four free lumbar vertebrae. With respect to the fused vertebrae, the vertebral body becomes thicker but narrower towards the posterior portion of the fragment. The contacts between each vertebra present an articular facet for the ribs. There is no sign of supplementary intervertebral articulations (i.e. xenarthrous articulations). Therefore, these vertebrae correspond to the fused anteriormost thoracic vertebrae, a condition similar to that of glyptodonts but contrasting with Pachyarmatherium (see Downing and White, 1995), armadillos and pampatheres.

Caudal vertebrae. Most of the caudal vertebrae are preserved inside the caudal armor, which precludes their description. The only element preserved out of this structure corresponds to one anterior caudal vertebra. The vertebral centrum is oval and the neural canal is rounded in cranial view and triangular in caudal view.

Femur. The femur (Fig. 4.1-2) is slenderer than that of

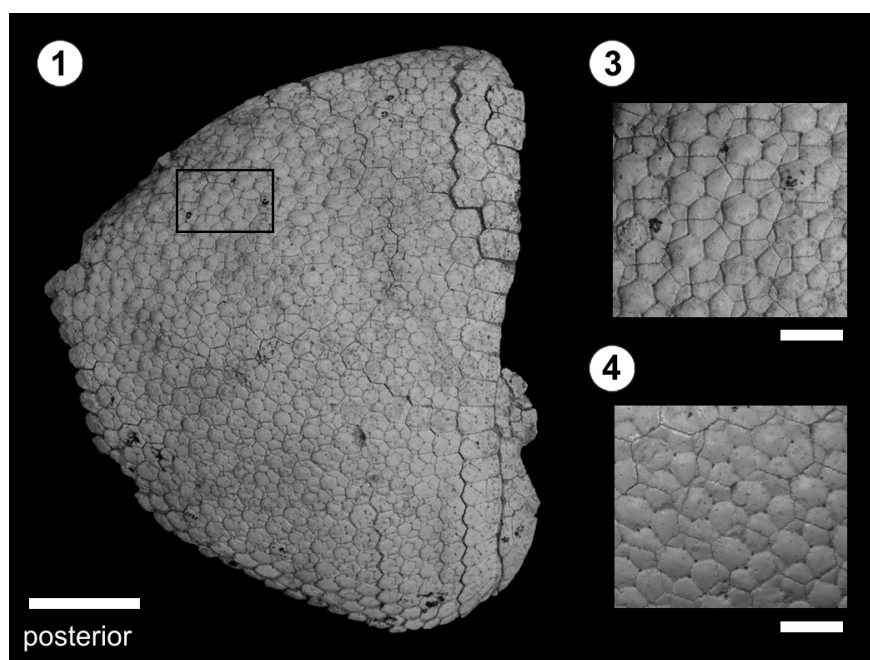

$(2)$

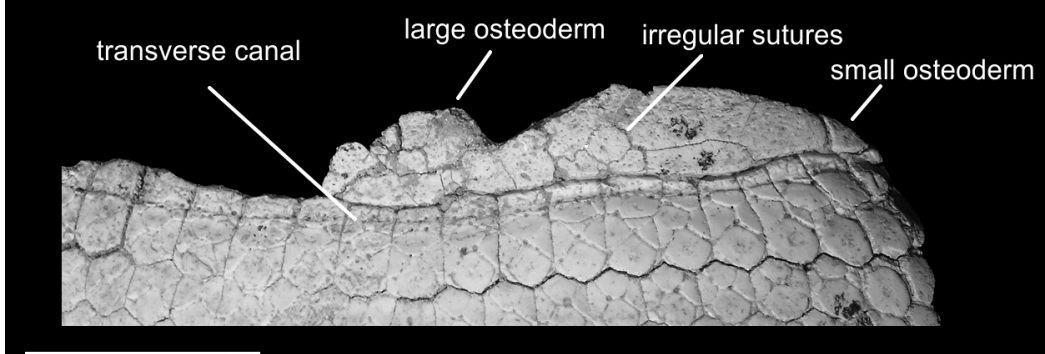

anterior

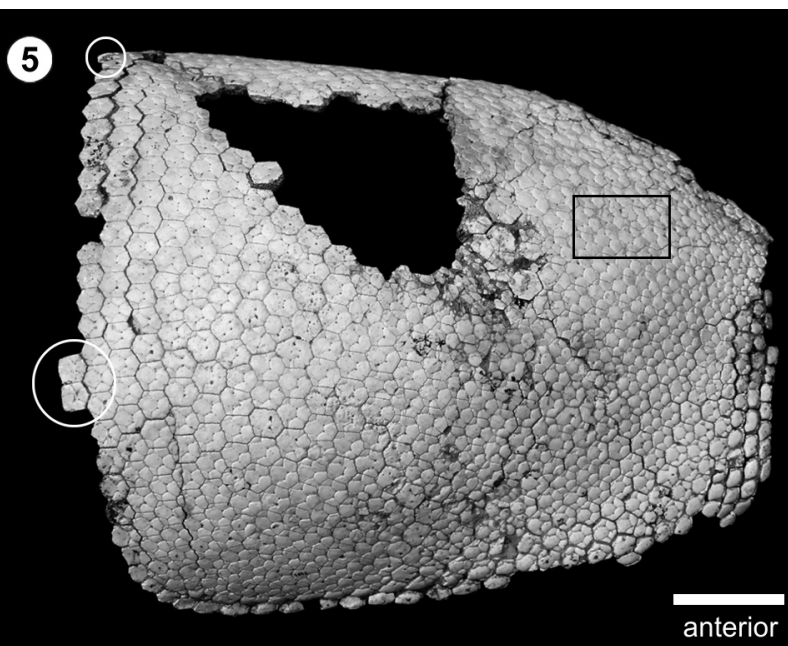

6

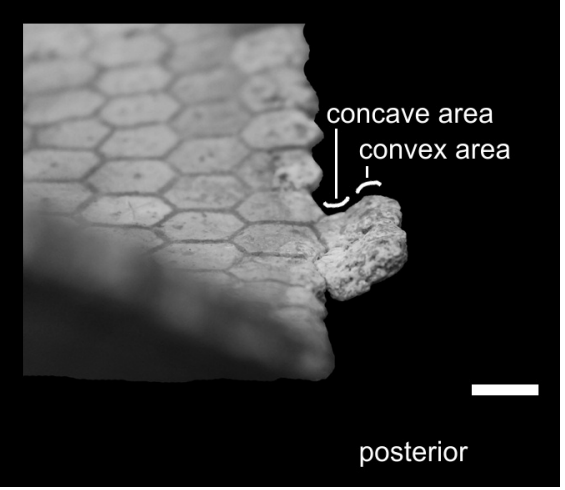

Figure 3. 1, Mirror image of the left pelvic shield (MNHN 1642) in lateral view; 2, mirror image of the part of the pelvic shield (MNHN 1642) in lateral view, detail of the preserved articulation area; 3, detail of the osteoderms of the pelvic shield, the rectangle in 3.1 marks the enlarged region; 4, detail of the osteoderms of the scapular shield, the rectangle in 3.5 marks the enlarged region; 5, right scapular shield (MNHN 1642) in lateral view; the circle identifies the three osteoderms from the last row; 6 , preserved articulation area of the right scapular shield (MNHN $1642)$ in internal view. Scale bar $=50 \mathrm{~mm}(1,2,5$ and 6$)$ and $10 \mathrm{~mm}(3$ and 4). 
glyptodonts, Pachyarmatherium and pampatheres, but more massive than that of armadillos. The femoral head is angled craniomedially. The neck is poorly developed and laterally oriented. The greater trochanter is strongly built, lateromedially compressed and laterally projected, but less so than in late-diverging glyptodonts and Pachyarmatherium. Like in armadillos, pampatheres and propalaehoplophorine glyptodonts, it is clearly projected above the femoral head. The trochanteric fossa is wide and shallow. The intertrochanteric line is poorly marked as in pampatheres and propalaehoplophorine glyptodonts. The third trochanter is rectangular, strongly laterally projected and positioned at midshaft, as in armadillos. The distal epiphysis is not laterally expanded as in pampatheres and glyptodonts. The lateral and medial epicondyles are slightly marked. The intercondyloid fossa is deeper cranially than it is caudally. The articular surface of both condyles is contiguous to the surface of the patellar trochlea.

Patella. The patella is oval, with the proximodistal axis larger than the lateromedial one, as in armadillos and pampatheres, and it is unlike late-diverging glyptodonts, in which both axes have a similar length. The cranial surface is convex. In the posterior surface, the oval facet for the medial condyle is wider than the oval facet for the lateral condyle.

Tibia-fibula. The tibial shaft is wider than the fibular shaft (Fig. 5.1-2). The distal epiphysis is more transversely extended than the proximal one, like in armadillos and Pachyarmatherium and unlike what occurs in glyptodonts. The medial condyle is oval, slightly elongated craniocaudally and mildly concave. The lateral condyle is roughly circular and slightly convex. The medial intercondylar eminence is more proximally projected than the medial one. The tibial tuberosity is stronger than in Eutatus but less prominent than in Dasypus. The tibial crest is well developed, as in most cingulates, and ends at the distal third of the tibial shaft, as in Pachyarmatherium and Euphractus. In this regard, it differs from Dasypus, in which the tibial ends in the proximal half, and from glyptodonts, in which it ends at the distal border of the tibial shaft. In anterior view, the tibial crest bends toward the lateral edge while its distal edge is strongly concave, as in Dasypus and Pachyarmatherium; it differs from glyptodonts and Euphractus, in which it is almost straight and gently convex. The fibular crest is well developed and ends at the proximal half, as in Dasypus, Pachyarmatherium and glyptodonts. As in other cingulates, a massive and strongly projected lateral malleolus is present; the medial malleolus is not as prominent. As in Dasypus and Pachyarmatherium, a caudally facing calcaneal facet is present. It has a convex surface unlike that of Dasypus and Pachyarmatherium, in which it is concave and flat, respectively. This facet, which is absent in glyptodonts, lies in a massive tubercle lateral to the tibial astragalar facets, as in Pachyarmatherium. As in this latter, a deep notch separates this tubercle from the lateral malleolus. The orientation and morphology of the tibial astragalar facets concurs with those of the homologous area in Pachyarmatherium: the facets are obliquely oriented relative to the long axis of the tibia-fibula, and the medial facet is smaller than the lateral one.

Calcaneum. The tuber is mediolaterally compressed (Fig. 6.1-3), as in Dasypus, Pachyarmatherium and Euphractus, with a slightly transversely expanded apex clearly contrasting with the massive tuber calcanei of glyptodonts. Its plantar side is slightly convex. Like in Pachyarmatherium, the groove for the calcaneal tendon is wide, elongated and deep, and somewhat displaced medially in relation with the median plane of the calcaneum. The groove for the tendon of the peroneus brevis is very deep and elongated, like in Pachyarmatherium, Propalaehoplophoridae, Pampatherium and Glyptodon, contrasting with Dasypus and Euphractus, in which it is shallow, and with Doedicurus and Panochthus, in which it is rudimentary. Plantar to this groove is the peroneus tubercle and plantar to this, there is a wide and deep groove for the tendon of the peroneus longus. The sustentacular process is triangular in plantar view. It is thin, like in Dasypus and Pachyarmatherium, and in contrast with Pampatherium and, especially, glyptodonts. Unlike that which happens in Pampatherium and Dasypus, a peroneal tubercle at the distolateral end of the calcaneum is present, as in Euphractus, Pachyarmatherium and Propalaehoplophorus. The ectal facet is oblong and weakly convex. The sustentacular facet is roughly triangular, convex and much shorter than the ectal one. These two facets are separated by a shallow interarticular sulcus, as in Dasypus, Euphractus and Pachyarmatherium, and in contrast with glyptodonts, in which this sulcus is deep, and, to a lesser extent, with Pampatherium, in which it is moderately deep. As in Pachyarmatherium, there is a flat and rounded fibular facet at the 
lateralmost border of the ectal facet, which is positioned in a much less developed fibular tubercle than that of Dasypus. A massive plantar tubercle lies on the plantar surface of the calcaneum. In the central portion of this tubercle, there is a narrow and deep groove for the calcaneocuboid ligament. The cuboid facet is broken in its cranial third. The preserved

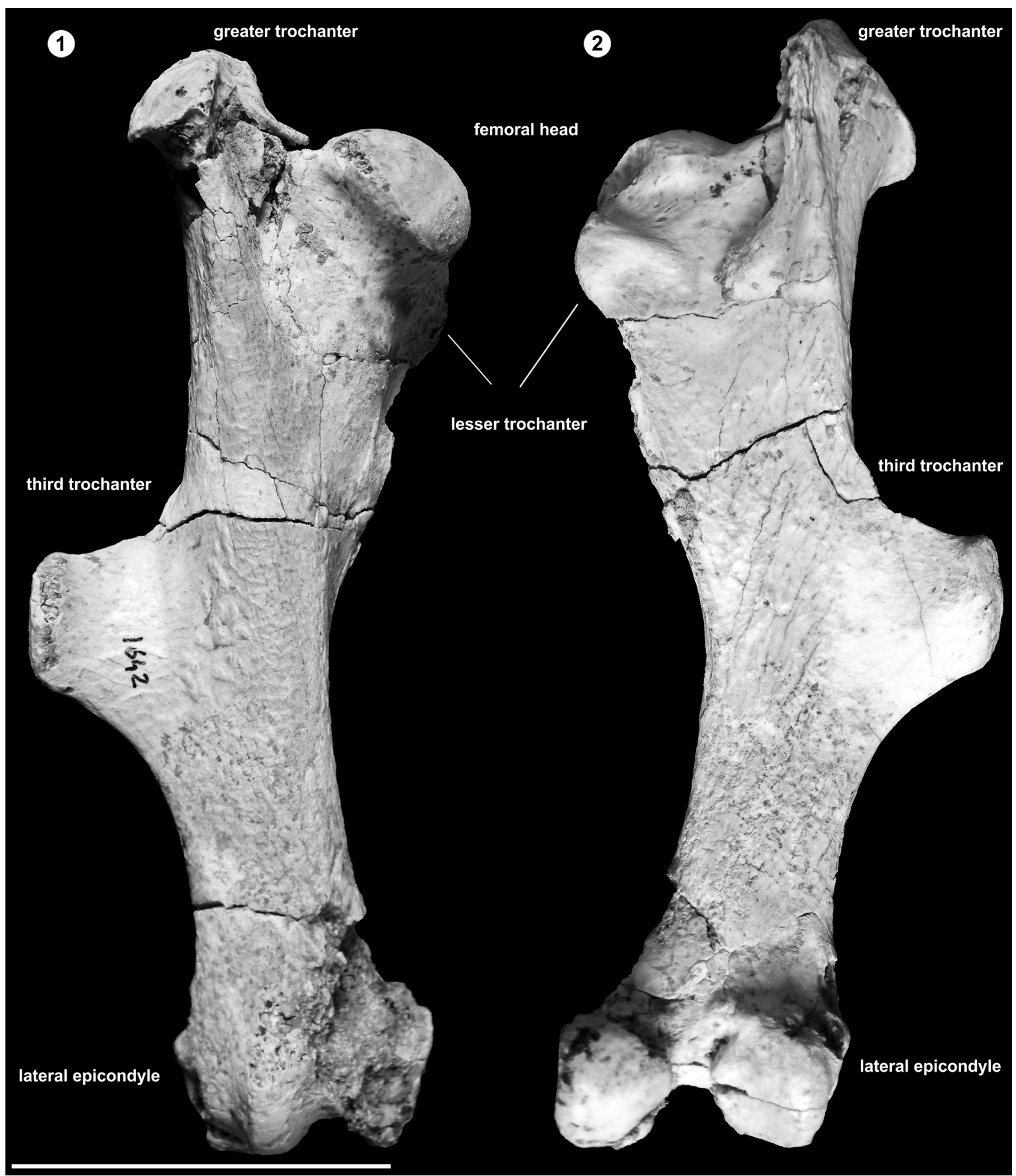

Figure 4. Right femur of the holotype (MNHN 1642). 1, cranial view; 2, caudal view. Scale bar= $50 \mathrm{~mm}$. 
part is rectangular, concave, and with its major axis oriented dorsoventrally. As in Pachyarmatherium and glyptodonts, the neck of the calcaneum is relatively short compared to that of armadillos and pampatheres.

Astragalus. The astragalus (Fig. 6. 1,4-5), as in other cingulates, has a strongly asymmetrical trochlea due to the greater development of its lateral crest, and the groove between the crests of the astragalar trochlea is wide and deep. As in Dasypus and Euphractus, the ectal facet is distinctly concave and triangular, in contrast with some glyptodonts, in which it is triangular and slightly concave (e.g., Propalaehoplophorus, Panochthus, Neosclerocalyptus) or flat and rectangular (e.g., Glyptodon, Doedicurus). The sustentacular facet is oblong and shorter than the ectal facet. The sulcus tali is wide and shallow in contrast with that of late-diverging glyptodonts. The tuberosity for the medial collateral ligament is as developed as in Euphractus, more so than in Dasypus, but less than in glyptodonts. In distal view, the facet for the navicular is roughly rectangular and oblique, with its lateromedial axis longer than the craniocaudal, as in Dasypus, Euphractus and Eutatus, and unlike Pampatherium, in which it is subrounded, and glyptodonts, in

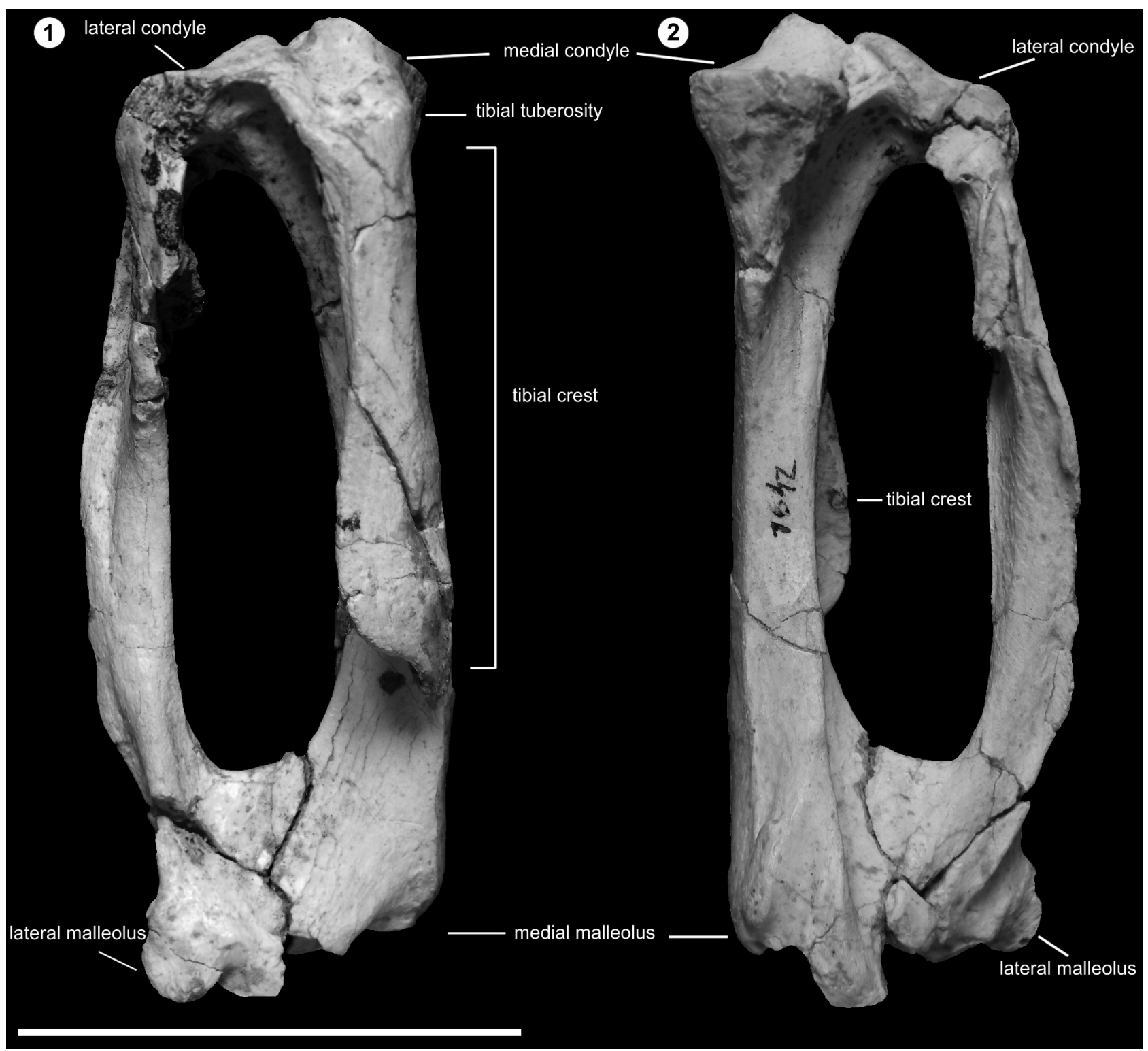

Figure 5. Right tibia-fibula of the holotype (MNHN 1642). 1, cranial view; 2, caudal view. Scale bar= $50 \mathrm{~mm}$. 
which it is roughly triangular. A poorly delimited navicular tuberosity occurs just proximal to the dorsal border of the navicular facet; it is similar to that of Euphractus and much less developed than in glyptodonts.

Navicular. The articular facet for the astragalus is lageniform and strongly concave, as in Dasypus, Pachyarmatherium, propalaehoplophorids and pampatheres, and unlike latediverging glyptodonts, in which it is subcircular and slightly concave. At the lateral side, the cuboid facet is oblong with its major axis dorsoplantarly. The facet for the plantar sesamoid is slightly oblong, as in Pachyarmatherium, Dasy- pus and propalaehoplophorids, and unlike late-diverging glyptodonts (e.g., Neosclerocalyptus), Holmesina and Euphractus in which it is strongly oblong. Like in Pachyarmatherium, Euphractus, pampatheres and Propalaehoplophoridae, the medial cuneiform facet is subtriangular in shape and oriented at an angle of nearly $90^{\circ}$ with respect to the lateral cuneiform facet.

Cuboid. In proximal view, the articular surface for the calcaneum is rectangular and convex. In plantar view, the plantar tubercle bears a subrounded articular facet for the sesamoid, like in Dasypus and Euphractus, instead of a triangular one,

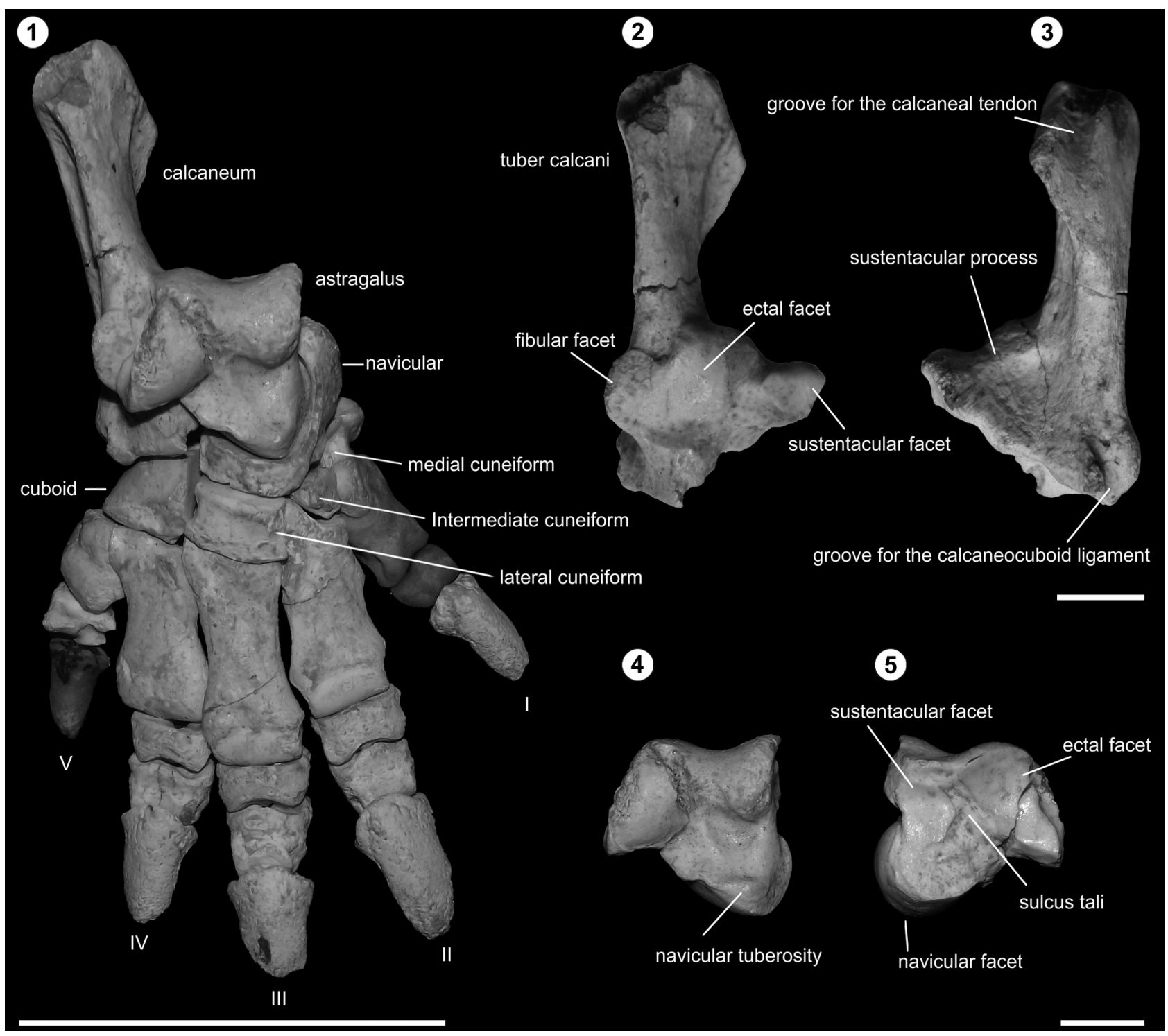

Figure 6. Right foot of the holotype (MNHN 1642). 1, articulated foot in cranial view; 2, right calcaneum in cranial view; 3, right calcaneum in caudal view; 4, right astragalus in cranial view; 5, right astragalus in caudal view. Scale bar= $50 \mathrm{~mm}(1)$ and $10 \mathrm{~mm}(2-5)$. 
as in glyptodonts. In distal view, there is a wide canal for the tendon of peroneus longus and two articular facets to metatarsals IV and V. This latter facet is more distally positioned than the former. In medial view, the facet for the navicular is rectangular and slightly concave. Next to it, there is a subtriangular and concave facet for the lateral cuneiform.

Cuneiforms. The medial cuneiform presents, cranially, a wide and deep sulcus for the tendon of peroneus longus. Distally, the articular facet for metatarsal I is strongly concave. Proximally, the facet for the navicular is notched; medial to it, there is a circular facet for metatarsal II. The intermediate cuneiform is elongated dorsoplantarly, with a concave facet for the navicular and a convex facet for metatarsal II. The lateral cuneiform bears a triangular proximal facet for the navicular. Its distal facet for metatarsal III is Tshaped with the transversal segment cranially positioned.

Metatarsals. The metatarsals (Fig. 6.1) do not present significant differences in relation to the homologous elements in armadillos, Pachyarmatherium and pampatheres. Among them, metatarsals I and V are the shortest while metatarsals II and III the longest. Metatarsal IV is of intermediate size. All metatarsals present a concave proximal articular surface and a convex distal articular surface with a welldeveloped median keel. As in pampatheres, armadillos and Propalaehoplophorus, this keel is more salient in such a way that its dorsoplantar extension is visible in distal view; in contrast with late-diverging glyptodonts, it reaches the distal articular surface whereas, in late-diverging glyptodonts, it is limited to the plantar side. The articular surfaces to the plantar sesamoids, like in armadillos, pampatheres and Pachyarmatherium, are remarkably shorter in proximodistal length than they are in late-diverging glyptodonts.

Phalanges. Digits I and II present two phalanges (proximal and ungual) whereas digits II, III and IV present three phalanges (proximal, middle and ungual) (Fig. 6.1). The ungual phalanges are proximodistally elongated. All phalanges present concave proximal articular surfaces and convex distal ones with a small median keel. The distal end of the ungual phalanges is blunt, like in Euphractus and Eutatus and unlike that of Dasypus, which is sharp.

\section{Phylogenetic Analysis}

One single most parsimonious tree was obtained by the maximum parsimony analysis (Tree Length $=367 ; \mathrm{Cl}=0.62$;
$\mathrm{RI}=0.74 ;$ Fig. 7). According to this hypothesis, the phylogenetic relationships among the glyptodonts are the same as those obtained by Fernicola (2008), Porpino et al., (2009, 2010) and Fernicola and Porpino (2012); however, in some nodes, new synapomorphies are recorded, whereas in others some previous unambiguoussynapomorphies become ambiguous.

In the obtained topology, node A represents the clade formed by Neoglyptatelus + Pachyarmatherium and its sister group formed by Pampatherium + Glyptodontia. The last group is supported by four unambiguous synapomorphies, two of which were found by Porpino et al. (2010; 84:1 and 86:1) and two of which are new: the greater trochanter of the femur lateral to the patellar trochlea (103:1) and an angle between the caudal border of the lesser trochanter and the transverse axis of the proximal epiphysis $\leq 40^{\circ}$ (106:0).

A new clade, herein denominated Pachyarmatheriidae, is formed by Neoglyptatelus and Pachyarmatherium (node B). This clade is supported by six unambiguous synapomorphies and has high bootstrap frequencies and Bremer support values (81 and 4, respectively): a cranial border of the tibial crest straight along its entire length (121:1), the ratio between the dorsoplantar length/transversal length of the sustentaculum of calcaneum > 2 (133:2), the presence of a groove for the fascia ligament in the lower plantar tubercle $(136: 1)$, the anterior border of the sustentacular facet in line or posterior to the anterior border of the ectal facet (137:0), the medial border of the ectal facet in line or slightly laterally relative to the lateral border for the sustentacular facet (138:0), and a dorsal carapace formed by anterior and posterior shields without transverse mobile band(s) between them (166:2).

This clade is the sister group of the clade formed by Pampatherium + Glyptodontia (node C), which is supported by ten unambiguous synapomorphies and has high bootstrap frequencies and Bremer support values (92 and 5, respectively). Six of these synapomorphies were previously found by Porpino et al. (2010; 85:1, 87:1, 97:1, 109:1, 110:1, and 143:1), whereas four represent new postcranial unambiguous synapomorphies: a lateral crest of the trochlea lateromedially oriented (118:1), the ratio between the dorsoplantar length/transversal length of the sustentaculum of calcaneum <1 (133:0), the lateral crest of the astragalar 
trochlea nearly at the same level than the medial one (140:1), and the medial portion of the astragalus between $<90 \%$, $>80 \%$ of the maximum width of the astragalus (146:1). The last three characters were modified from Porpino et al. (2010).

The Glyptodontia (sensu Fernicola 2008; node D) is strongly supported by 42 unambiguous synapomorphies and has good bootstrap frequencies and Bremer support values (99 and 28, respectively). Of these 42 synapomorphies, 29 has been previously found by Fernicola (2008;
$3: 2,5: 1,6: 0,8: 1,9: 1,14: 2,15: 1,18: 0,23: 2,25: 1,30: 1,39: 2$, 41:1, 45:1, 47:1, 54:1, 56:1, 5:2, 60:1, 62:1, 64:2, 66:2, 67:1, 69:1, 71:2, 71:2, 78:1, 81:1, and 83:1), four by Porpino et al. (2010; 100:1, 128:1, 131:1, and 139.1), one by Fernicola and Porpino (2012; 166.1), and eight represent new postcranial synapomorphies: an absent or poorly defined cranial depression between the head and the greater trochanter of the femur (107:0), the length between the proximal border of the third trochanter and the proximal border of the greater trochanter being greater than $50 \%$ of the maximum

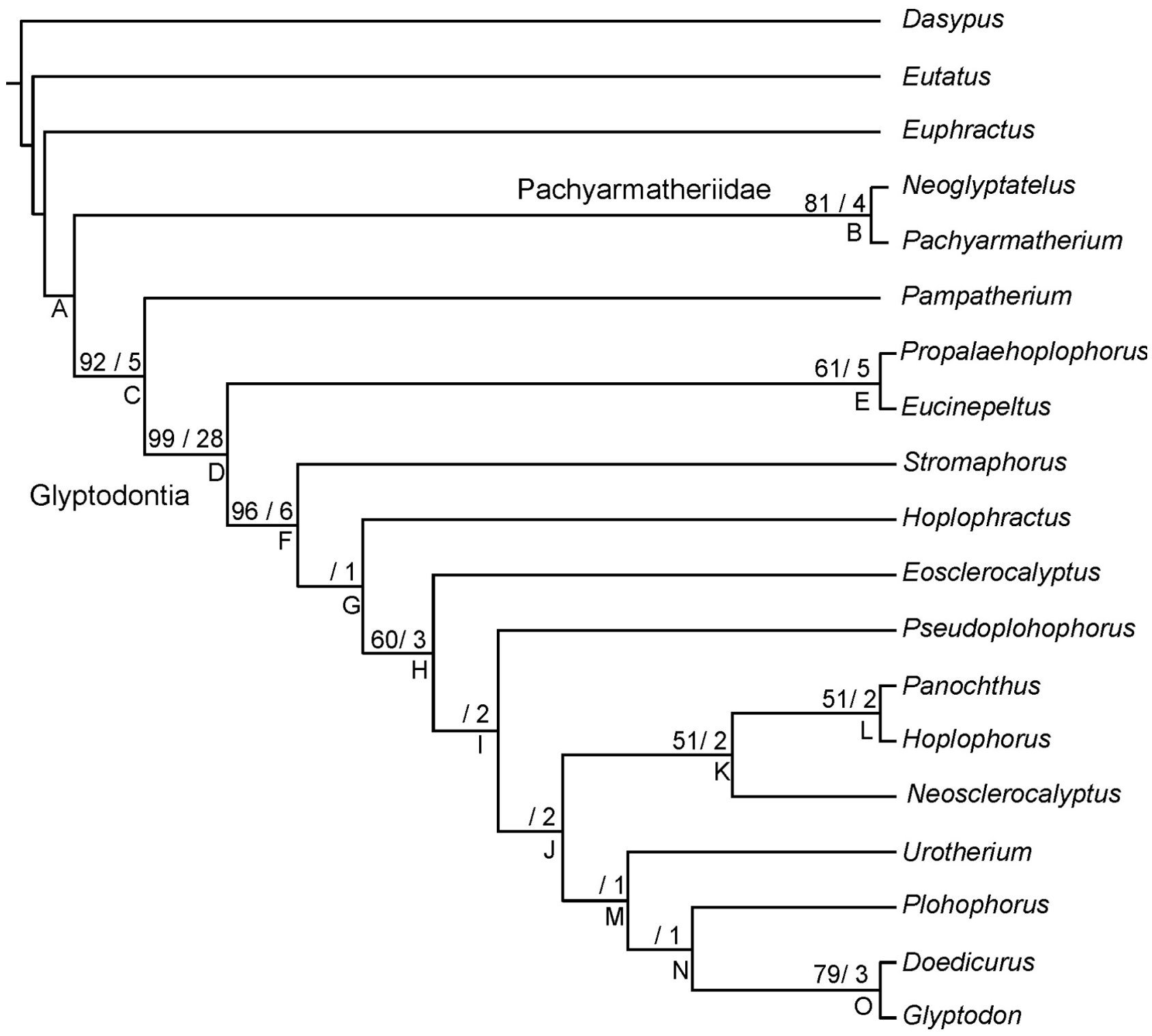

Figure 7. Most parsimonious tree resulting from the cladistic analysis. Capital letters represent the nodes discussed in the text. The number immediately above and to the left of each node represents a bootstrap value, and the second one and at the right, the Bremer support. 
length of the femur (108:2), the length of the medial margin of the femoral neck being smaller than the length of its lateral margin (112:2), absent or poorly developed trochanteric fossa (116:0), the smooth surface of the ectal facet of calcaneum (125:1), a deep interarticular sulcus between the astragalar facets of the calcaneum (126:2), the ratio between the length of the ectal facet of calcaneum and the length of the neck of calcaneum > 2 (129:2), and transverse width of calcaneum at the level of very wide astragalar facets (130:1).

The internal relationships within Glyptodontia show a basal dichotomy between Propalaehoplophoridae (sensu Fernicola, 2008; node E) and the remaining glyptodonts (Glyptodontoinei sensu Fernicola, 2008; node F). Node E is supported by two unambiguous synapomorphies previously found by Fernicola (2008; 29.2 and 49.3). Node F is a wellsupported clade (bootstrap $=96 \%$; Bremer $=6$ ) diagnosed by seven unambiguous synapomorphies. Six of these had been previously found by Fernicola (2008: 20:2, 35:1, 36:1; 64:3, 80:0, and 82:2) whereas one, by Porpino et al. (2010; 157:2).

The following clades, represented by the nodes $\mathrm{G}, \mathrm{H}$ and I, have the same synapomorphies than those observed in the previous analysis. Node G is supported by one unambiguous synapomorphy previously found by Fernicola (2008; 2:3). Node H is supported by six unambiguous synapomorphies, two of which were found by Fernicola (2008; 41:0 and 43:1) while the remaining ones were found by Porpino et al. (2009: 86:2, 88:2, 89:1, and 90:1). Node I is supported by two unambiguous synapomorphies previously found by Fernicola (2008; $45: 2$ and 46:2).

The Glyptodontoidea (node J) is supported by three synapomorphies. Two of these were previously found by Fernicola (2008; 15:0 and 25:0), and one was previously found Porpino et al. (2010; 93:1). The Glyptodontoidea are composed of two clades: the Panochthidae (node K) and one group (node M) formed by Urotherium as a sister group of Glyptodontidae (Node M). In the first, Neosclerocalyptus is placed as the sister group to Hoplophorus + Panochthus in node L (Panochthidae sensu Fernicola, 2008), which is supported by 14 unambiguous synapomorphies of which eleven were found by Fernicola (2008: (2:3, 29:2, 31:2, 45:1, $46: 3,53: 1,54: 1,55: 2,58: 1,73: 1$ and 77:1) and three were found by Porpino et al. (2009: 85:1, 87:1, and 116:1). Three characters were resolved as synapomorphies of this clade in Porpino et al. (2010); yet, in this study, they do not present such status: character 117 from Porpino et al. (2010)angle between the major axis of the ectal facet and the long axis of the calcaneum-has a greater variability than that which had been previously found and has thus become non-informative. Character 135 corresponds with the character 129 from Porpino et al. (2010). In this case, the character is solved as an ambiguous synapomorphy. Finally, character 140 corresponds to a modification of character 131 from Porpino et al. (2010), which included a new state and reformulation of the previous ones. In this new scheme, the assigned states are not resolved as a synapomorphy of this node.

The second group (node M), formed by Urotherium as sister group of Glyptodontidae (Node N), is supported by one unambiguous synapomorphy found by Fernicola (2008; 74:2). Urotherium is characterized by two synapomorphies found by Fernicola (2008: 26:4 and 70:0), and one found by Fernicola and Porpino (2012; 163:3). The Glyptodontidae is supported by two unambiguous synapomorphies found by Fernicola (2008; 81:3 and 83:0); within this clade, Plohophorus is characterized by one apomorphy found by Fernicola and Porpino (164:2), and the monophyletic group Doedicurus + Glyptodon (node 0 ) is supported by four unambiguous synapomorphies found by Fernicola (2008: 41:1, 77:1, 79:2, and 80:0).

\section{DISCUSSION}

\section{Carapace structure and movement}

The presence in the Pachyarmatherium + Neoglyptatelus clade of large pelvic and scapular shields overlapping each other without separate transverse mobile band(s) is unique among cingulates (Figs. 2.1-3, 3.1-4). Excluding the new group, two main types of general arrangements of osteoderms along the middle dorsal line of the dorsal carapace can be recognized (Ameghino, 1889; Scott, 1903-04; Engelmann, 1985). The glyptodont type represents a pattern in which the osteoderms articulate with each other forming an undivided carapace without separate shields or transverse mobile bands crossing the carapace from side to side. The other general morphological type includes the remaining cingulates, characterized by the presence of transverse bands of imbricated osteoderms crossing the carapace from side to side. In some cases, these bands vir- 
tually occupy the whole carapace (e.g., Stegotherium Ameghino, 1887a, Peltephilus Ameghino, 1887a) while, in others, the posterior osteoderms form a pelvic shield and are preceded by transverse mobile bands crossing the carapace from side to side over the lumbar and thoracic regions of the vertebral column (e.g., Proeutatus). Finally, there are those in which the cranial osteoderms form a scapular shield separated from the pelvic shield by transverse mobile bands crossing the carapace form side to side (e.g., Tolypeutes, Dasypus).

In terms of carapace movement, the articular region of Neoglyptatelus uruguayensis is clearly defined by the transverse sulci that run through the ventral surface of the last two rows of the scapular shield and the dorsal surface of the second row of the pelvic shield (Fig. 3.1-4). This morphology suggests a movable articulation over one another, like a hinge, although it may have allowed some slide between them with the main movement axis represented by the central region of the articular zone. Considering the length between the transverse sulcus of the first complete row of the pelvic shield and the anterior border of the large lateroventral osteoderm, the maximum relative displacement between the shields of the carapace in the ventrolateral region would be of about $25 \mathrm{~mm}$.

While a comprehensive comparison is not possible and is beyond the scope of this contribution, the range of movements in the carapace of $N$. uruguayensis includes some dorsoventral flexion. This flexion is certainly more restricted than in the remaining cingulates, in which complete transverse bands of imbricated osteoderms are present but less limited than in glyptodonts in which complete transverse bands are absent. In N. uruguayensis, this movement is severely compromised by the virtually immobile carapace and the extensive vertebral fusions in the thoracic and lumbar regions of the vertebral column, also present in glyptodonts (Scott 1903-04).

Finally, regarding Pachyarmatherium, and according to Downing and White (1995), the scapular shield and the pelvic shield overlap each other by a single immovable transverse row of osteoderms in each shield (instead of two, as in N. uruguayensis). This type of articulation is very different from that of Neoglyptatelus and, as in Pachyarmatherium, the articular surface between both shields is flat. Therefore, it appears that the Pachyarmatherium carapace was more limited in terms of dorsoventral movement than that of Neoglyptatelus, at least in comparison with the new species herein described.

From a phylogenetic perspective, both glyptodonts and Pachyarmatheriidae are characterized by a tendency toward limiting carapace mobility, which was attained via distinct trajectories. In glyptodonts, it apparently involved the loss of the imbricated osteoderm bands from the top of the dorsal region towards the lateral border, with a concomitant fusion of the shields and some taxa retaining vestigial imbricating areas in certain zones of the lateral region (e.g., Propalaehoplophorus); in Pachyarmatheriidae, the restriction in mobility was attained by the loss of the complete transverse mobile band(s), with the retention of separate shields, but resulting in distinct articular regions between them in each genera, which also likely allowed the abovementioned distinct grades of mobility. It is curious that this clade, formed by only two genera, presents a greater variation of carapace mobility in comparison with the taxonomically diverse glyptodonts, in which the variation in carapace mobility is solely represented by the presence or absence of a vestigial lateroventral mobile region.

\section{Phylogenetic considerations: are glyptatelines glyptodonts?}

The expanded matrix used in this paper not only provides a test for the position of the Neoglyptatelus but also allows the reevaluation of the broad phylogenetic relationship of glyptodonts. In this regard, the internal relationships within Glyptodontia are identical to those obtained by Porpino et al. (2010) and Fernicola and Porpino (2012) (Fig. 7).

With respect to Neoglyptatelus, our phylogenetic analysis shows that this taxon, like Pachyarmatherium (see also Porpino et al., 2009), is not a glyptodont (Fig. 7). This raises an important question: are the remaining taxa, which had been previously assigned to Glyptatelinae, glyptodonts? This is quite an elusive problem as these taxa are based on scarce material-the very reason for their exclusion from our matrix and that of previous studies, except for that of Croft et al., (2007). However, these latter authors included only a single external group, Pampatheriidae, which implies the assumption that the Glyptatelinae were glyptodonts. As we claimed earlier, Lomaphorelus, which was previously 
regarded as a member of Glyptatelinae, is in fact a nomen dubium (Vizcaíno et al., 2003), so that the question exclusively concerns Glyptatelus and Clypeotherium. After McKenna et al. (2006) reassigned the teeth Ameghino (1897) had attributed to Glyptatelus to Pseudoglyptodon (an unusual sloth with glyptodont-like teeth), this genus and Clypeotherium are known only from a few osteoderms, which, in the case of Clypeotherium, are somewhat damaged.

There are some character states of osteoderms that are shared by Glyptatelus and Clypeotherium: (i) both have quite thick osteoderms, in contrast with most armadillos or pampatheres; and (ii) they present a posteriorly displaced main figure. Yet, these character states occur in other taxa. Similarly, thick osteoderms, for instance, are typical of glyptodonts and are homoplastic between these latter and Pachyarmatherium (Porpino et al., 2009) and, taking into consideration the results of our phylogenetic analysis, Neoglyptatelus. A posteriorly displaced main figure is also found in some basal glyptodonts such as Propalaehoplophorus (in some osteoderms; see Scott, 1903) and Parapropalaehoplophorus (in all known osteoderms; see Croft et al., 2007), as well as in different armadillos (e.g., Dasypus), and likely represents a plesiomorphic condition (see also Croft et al., 2007). Therefore, concerning the external morphology of the available osteoderms - the only known elements for Glyptatelus and Clypeotherium - there is no clear evidence allying these genera with glyptodonts, nor is there a potential synapomorphy to suggest the recognition of Glyptatelinae (minimally represented by Glyptatelus + Clypeotherium) as a clade. However, there are histological characters in osteoderms of Glyptatelus that are more similar to those of glyptodonts (thinner superficial and deep layers of compact bone; Carlini et al., 2008) than to those of Pachyarmatherium and Neoglyptatelus, which present osteoderms with a dasypodid-like histology (e.g., thicker superficial and deep layers of compact bone; see Carlini et al., 2008 and Da Costa Pereira et al., 2014). These histological features are the best evidence to date, suggesting that at least Glyptatelus could represent an earlier glyptodont rather than being a member of another cingulate lineage.

\section{Paleobiogeographic implications}

The genus Pachyarmatherium is widely represented in America by three species. Pachyarmatherium leiseyi Downing and White, 1995, the type species, has been recorded in North America from the late Pliocene to the Early Pleistocene of Florida and in the late Pliocene of South Carolina (Downing and White, 1995 and Hulbert, 2001), in the late Blancanearly Irvingtonian of Central America (Laurito et al., 2005, Laurito and Valerio 2012) and in the Plio-Pleistocene of Venezuela (Rincón et al., 2009, Solórzano et al. 2015). In South America, the species Pachyarmatherium tenebris has been recorded in the late Pleistocene of Venezuela and Perú (Rincón and White, 2007; Martinez et al., 2008; Martinez and Rincón, 2010) while a different species_-Pachyarmatherium brasiliense Porpino, Fernicola and Bergqvist, 2009-has been proposed for the late Pleistocene to early Holocene of Brazil (Porpino et al., 2009; Oliveira et al., 2009) although some dispute exists concerning their synonymy (e.g., Oliveira et al., 2013; Solórzano et al., 2015; see Material and Methods). Finally, Pachyarmatherium sp. was recorded in the Quaternary of Uruguay and Southern Brazil (Bostelmann et al., 2008). This temporal distribution implies a ghost lineage from the late Miocene on the branch that leads to Pachyarmatherium because its sister group, Neoglyptatelus, was recorded from the middle-late? Miocene of Colombia and the late Miocene of Uruguay, South America. In this context, this clade would have originated in South America, and the absence of Pachyarmatheriidae in North and Central America before the late Pliocene could be related with the absence of a wide and constant terrestrial connection among the Americas in the late Miocene (Woodburne, 2010, O'Dea et al., 2016). The presence of Pachyarmatherium leiseyi in the three subcontinents and the existence of $P$. tenebris and $P$. brasiliensis in South America supported the hypothesis that the first species migrated towards the north during the Plio-Pleistocene, when terrestrial connections were stable and broad (Woodburne, 2010; O'Dea et al., 2016).

\section{CONCLUSIONS}

The new species, Neoglyptatelus uruguayensis, has osteoderms with smaller foramina and narrower sulci than in $N$. originalis, as well as osteoderms from the dorsal section of the pelvic region with more peripheral figures and more convex surfaces in comparison to those of $N$. sincelejanus. Based on the maximum parsimony analysis, we conclude that Neoglyptatelus is not a glyptodont and comprises, together with Pachyarmatherium, a new clade herein named 
Pachyarmatheriidae and supported by six unambiguous synapomorphies (five from the postcranial skeleton and one from carapace). This clade would have originated in South America and reached Central and North America during the Plio-Pleistocene, in which it is represented by Pachyarmatherium leiseyi. The members of Pachyarmatheriidae present a carapace formed by large scapular and pelvic shields, in contrast with the undivided carapace of glyptodonts and more similar to the remaining cingulates but differing from these in not having transverse mobile bands. The articulation zone between the shields shows differences between Neoglyptatelus and Pachyarmatherium but, based on the available evidences in both genera, would allow some limited dorsoventral flexion (perhaps more limited in the latter) in contrast with glyptodonts (in which this flexion was likely absent) and the remaining cingulates (in which this flexion is/was less limited). This shows that the evolution of the cingulate carapace proved more complex than previously thought.

\section{ACKNOWLEDGMENTS}

We are grateful to A. A. Carlini for the images of Neoglyptatelus originalis rendered for this study, and to C. de Muizon, L.R. González-Ruiz and R.K. McAfee for their thoughtful comments and suggestions for improving the manuscript. We are especially indebted to R. Vayra for his illustration in figure 1. We thank Alejandra Castiñeira and Evangelos Vlachos who generously helped us with the specific epithet. This work was partially supported by Universidad Nacional de Luján, grant CCD-CD: 054/12 and CONICET-PIP 781, PICT 20162665 to J.C. Fernicola; Conselho Nacional de Desenvolvimento Científico e Tecnológico - CNPq (grant 308013/ 2015-8, for KOP). PICT 2013-0389 UNLP 11/N750 (SFV).

\section{REFERENCES}

Ameghino, C. 1919. Sobre mamíferos fósiles del piso araucanense de Catamarca y Tucumán. Primera Reunión Nacional de la Sociedad Argentina de Ciencias Naturales (Tucumán, 1916), Actas 150-153.

Ameghino, F. 1887a. Enumeración sistemática de las especies de mamíferos fósiles coleccionados por Carlos Ameghino en los terrenos Eocenos de Patagonia Austral y depositado en el Museo de La Plata. Boletín del Museo de La Plata 1: 1-26.

Ameghino, F. 1887b. Apuntes preliminares sobre algunos mamíferos estinguidos del yacimiento de "Monte Hermoso" existentes en el "Museo de La Plata". Boletín del Museo de La Plata 1: 1-20.

Ameghino, F. 1888. Lista de las especies de mamíferos fósiles del Mioceno superior de Monte Hermoso hasta ahora conocidas. P.E. Coni, Buenos Aires, $21 \mathrm{p}$.

Ameghino, F. 1889. Contribución al conocimiento de los mamíferos fósiles de la República Argentina. Actas de la Academia Nacional de Ciencias de Córdoba 6: 1-1027.

Ameghino, F. 1891. Nuevos restos de mamíferos fósiles descubiertos por Carlos Ameghino en el Eoceno inferior de la Patagonia austral. Especies nuevas, adiciones y correcciones. Revista Ar- gentina de Historia Natural 1: 289-328.

Ameghino, F. 1897. Les Mammifères crétacés de I'Argentine. Deuxième contribution à la connaissance de la faune mammalogique des couches à Pyrotherium. Boletín del Instituto Geográfico Argentino 18: 406-521.

Ameghino, F. 1902. Notices préliminaires sur des mamifères nouveaux des terrains crétacés de Patagonie. Boletín de la Academia Nacional de Ciencias de Córdoba 17: 5-70.

Bossi, J., and Navarro, R. 1991. Geología del Uruguay. Departamento de Publicaciones de la Universidad de la República, Montevideo, $970 \mathrm{p}$.

Bostelmann, E., Rinderknecht, A., and Pereira, J. 2008. Primeros registros de Glyptatelinae cuaternarios (Mammalia, Xenarthra), para el cono sur de Sudamérica. III Congreso Latinoamericano de Paleontología (Neuquén), Resúmenes p. 29.

Bostelmann, E., and Rinderknecht, A. 2010. First Neogene Typotheria (Mammalia, Notoungulata, Hegetotheriidae) of Uruguay. I Congreso Uruguayo de Zoología (Montevideo), Actas p. 74.

Brandoni, D. 2013. Los mamíferos continentales del "Mesopotamiense" (Mioceno Tardío) de Entre Ríos, Argentina. Diversidad, edad y paleobiogeografía. In: D. Brandoni and J. Noriega (Eds.), El Neógeno de la Mesopotamia argentina. Asociación Paleontológica Argentina, Publicación Especial, Buenos Aires, p. 179-191.

Burmeister, G. 1866. Lista de los mamíferos fósiles del terreno diluviano. Anales del Museo Público de Buenos Aires 1: 121-232.

Cabrera, A. 1939. Sobre vertebrados fósiles del Plioceno de Adolfo Alsina. Revista del Museo de La Plata (nueva serie, Paleontología) 2: 3-35.

Burmeister, G. 1874 Monografía de los gliptodontes en el Museo Público de Buenos Aires. Anales del Museo Público de Buenos Aires 2: 355-412.

Carlini, A.A., Vizcaíno, S.F., and Scillato-Yané, G.J. 1997. Armored xenarthrans: a unique taxonomic and ecologic assemblage. In: R.F. Kay, R.L. Cifelli, J.J. Flynn, and R.H. Madden (Eds.), Vertebrate Paleontology of the Miocene Honda Group, Republic of Colombia. Smithsonian Institution Press, Washington, p. 213-226.

Carlini, A.A., Zurita, A.E., Scillato-Yané, G.J., Sánchez, R., and Aguilera, O. 2008. A new glyptodont species from Codore Formation (Pliocene), Estado Falcón (Venezuela), and the Asterostemma' problem. Paläontologische Zeitschrift 82: 139-152.

Castellanos, A. 1926. Sobre un nuevo gliptodóntido chapadmalense, Urotherium simplex n. gen. et n. sp. y las formas afines. Anales del Museo Nacional de Historia Natural de Buenos Aires 34: 263278.

Cozzuol, M.A. 2006. The Acre vertebrate fauna: Age, diversity, and geography. Journal of South American Earth Sciences 21: 85-203.

Croft, D.A., Flynn, J.J., and Wyss, A.R. 2007. A New Basal Glyptodontid and other Xenarthra of the Early Miocene Chucal Fauna, Northern Chile. Journal of Vertebrate Paleontology 27: 781-797.

Da Costa Pereira, V.L.G., Victer, G.D., Porpino, K.D.O., and Bergqvist, L.P. 2014. Osteoderm histology of Late Pleistocene cingulates from the intertropical region of Brazil. Acta Palaeontologica Polonica 59: 543-552.

Downing, K.F., and White, R.S. 1995. The cingulates (Xenarthra) of the Leisey Shell Pit local fauna (Irvingtonian), Hillsborough County, Florida. Bulletin of the Florida Museum of Natural History 37: 375-396.

Engelmann, G.F. 1985. The Phylogeny of the Xenarthra. In: G.G. Montgomery (Ed.), Ecology of Armadillos, Sloths, and Vermilinguas. Smithsonian Institution Press, Washington and London, p. 51-64.

Engelmann, G.F. 1987. A new Deseadan sloth (Mammalia: Xe- 
narthra) from Salla, Bolivia, and its implications from the primitive condition of the dentition in edentates. Journal of Vertebrate Paleontology 7: 217-223.

Fernicola, J.C. 2008. Nuevos aportes para la sistemática de los Glyptodontia Ameghino 1889 (Mammalia, Xenarthra, Cingulata). Ameghiniana 45: 553-574.

Fernicola, J.C., and Porpino, K.O. 2012. Exoskeleton and systematics: a historical problem in the classification of glyptodonts. Journal of Mammalian Evolution 19: 171-183.

Gaudin, T.J., and Wible, J.R. 2006. The phylogeny of living and extinct armadillos (Mammalia, Xenarthra, Cingulata): a cranio-dental analysis. In: M.T. Carrano, T.J. Gaudin, R.W. Blob, and J.R. Wible (Eds.), Amniote Paleobiology: Perspectives on the Evolution of Mammals, Birds and Reptiles. The University of Chicago Press, Chicago, p. 153-198.

Gervais, P. 1867. Sur une nouvelle collection d'ossements fossiles de mammiféres recueillé par M. Fr. Seguin dans la Confédération Argentine. Comptes Rendus des Séances de l'Académie des Sciences 65: 279-282.

Gervais, H., and Ameghino, F. 1880. Les mammifères fossiles de l'Ámérique du Sud. Paris-Buenos Aires, 225 p.

Goloboff, P.A., and Catalano, S.A. 2016. TNT version 1.5, including a full implementation of phylogenetic morphometrics. Cladistics 32: $221-238$.

González-Ruiz, L.R., Zurita, A.E., Scillato-Yané, G.J., Zamorano, M., and Tejedor, M.F. 2011. Un nuevo Glyptodontidae (Mammalia, Xenarthra, Cingulata) del Mioceno de Patagonia (Argentina) y comentarios acerca de la sistemática de los gliptodontes "friasenses". Revista mexicana de Ciencias Geológicas 28: 566-579.

Hill, R.V. 2006. Comparative anatomy and histology of xenarthran osteoderms. Journal of Morphology 267: 1441-1460.

Hoffstetter, R. 1958. Xenarthra. In: J. Piveteau (Ed.), Traité de Paléontologie. Masson et Cie, Paris, p. 535-636.

Hulbert, R.C. 2001. Xenarthrans. In: R.C. Hulbert (Ed.), The Fossil Vertebrates of Florida. University Press of Florida, Gainesville, p. 175-187.

Illiger, C. 1811. Prodromus systematis mammalium et avium additis terminis zoographicis utriusque classis. C. Salfeld, Berolini, $301 \mathrm{p}$.

Krmpotic, C.M., Ciancio, M.R., Barbeito, C., Mario, R.C., and Carlini, A.A. 2009. Osteoderm morphology in recent and fossil euphractine xenarthrans. Acta Zoologica 90: 339-351.

Laurito, C., Zamora, A.L.V., and Gamboa, E.A.P. 2005. Los xenarthras fósiles de la localidad de Buenos Aires de Palmares (Blancano tardío-Irvingtoniano temprano), provincia de Alajuela, Costa Rica. Revista Geológica de América Central 33: 83-90.

Laurito, C.A., and Valerio, A.L. 2012. Paleobiogeografía del arribo de mamíferos suramericanos al sur de América Central de previo al Gran Intercambio Biótico Americano: un vistazo al GABI en América Central. Revista Geológica de América Central 46: 123-144.

Linnaeus, C. 1758. Systema naturae per regna tria naturae, secundum classes, ordines, genera, species, cum characteribus, differentiis, synonymis, locis, Editio Decima, reformata. Laurentii Salvii, Stockholm, $824 \mathrm{p}$.

Lund, P.W. 1839. Blik paa Brasiliens dyreverden för sidste jordomvaeltning. Anden afhandling: Pattedyrene (Lagoa Santa d. 16 de novbr. 1837). Det kongelige Danske Videnskabernes Selskabs naturvidenskabelige og mathematiske Afhandlinger 8: 61-144.

McKenna, M.C., and Bell, S.K. 1997. Classification of mammals above the Species Level. Columbia University Press, New York, 631 p.

McKenna, M.C., Wyss, A.R., and Flynn, J.J. 2006. Paleogene pseudoglyptodont xenarthrans from central Chile and Argentine Patagonia. American Museum Novitates 3536: 1-18.
Madden, R.H., Guerrero, J., Kay, R.F., Flynn, J.J., Swisher III, C.C., and Walton, A.H., 1997. The Laventan Stage and Laventan Age: new chronostratigraphic and geochronologic units for the Miocene of South America. In: R.F. Kay, R.H. Madden, R.L. Cifelli, and J.J. Flynn (Eds.), Vertebrate Paleontology in the Neotropics. Smithsonian Institution Press, Washington, p. 499-519.

Martinez, J.N., Fernicola, J.C., and Vizcaíno, S. 2008. Presencia de Pachyarmatherium Downing and White, 1995 en el Pleistoceno de La Encantada (Morropón, Piura): primer registro para el Perú. $7^{\text {er }}$ Congreso de la Sociedad Peruana de Mastozoología (Perú), Actas 59.

Martinez, J.N., and Rincón, A.D. 2010. Los Xenarthra Cingulata del noroeste del Perú. Resúmenes extendidos del XV Congreso Peruano de Geología, Publicación Especial de la Sociedad Geológica del Perú (Perú), Actas 9: 432-435.

O'Dea, A., Lessios. H.A., Coates, A.G., Eytan, R.I., Restrepo-Moreno, S.A., Cione, A.L., Collins, L.S., de Queiroz, A., Farris, D.W., Norris, R.D., Stallard, R.F., Woodburne, M.O., Aguilera, O., Aubry, M., Berggren, W.A., Budd, A.F., Cozzuol, M.A., Coppard, S.E., DuqueCaro, H., Finnegan, S., Gasparini, G.M., Grossman, E.L., Johnson, K.G., Keigwin, L.D., Knowlton, N., Leigh, E.G., Leonard-Pingel, J.S., Marko, P.B., Pyenson, N.D., Rachello-Dolmen, P.G., Soibelzon, E., Soibelzon, L., Todd, J.A., Vermeij, G.J., Jackson, J.B.C. 2016. Formation of the Isthmus of Panama. Science Advances 2: e1600883.

Oliveira, E.V., Franca Barreto, A.M., and da Silva Alves, R. 2009. Aspectos sistemáticos, paleobiogeográficos e paleoclimáticos dos mamíferos quaternários de Fazenda Nova, PE, nordeste do Brasil. Gaea Journal of Geoscience 5: 75-85

Oliveira, E.V., Porpino, K.O., and Silva, F.M. 2013. New material of Pachyarmatherium from the late Pleistocene of northeastern Brazil: insights into its morphology and systematics. Paläontologische Zeitschrift 87: 505-513.

Owen, R. 1839. Description of a tooth and part of the skeleton of the Glyptodon, a large quadruped of the Edentate order, to which belongs the tessellated bony armour figured by Mr. Clift in his memoir on the remains of the Megatherium, brought to England by Sir Woodbine Parish, F.G.S. Proceedings of the Geological Society of London 3: 108-113.

Paula Couto, C. de. 1957. Sôbre um gliptodonte do Brasil. Boletin Divisão de Geologia e Mineralogia 165: 1-37.

Perea, D. 2005. Pseudoplohophorus absolutus n. sp. (Xenarthra, Glyptodontidae), variabilidad en Sclerocalyptinae y redefinición de una biozona del Mioceno Superior de Uruguay. Ameghiniana 42: 175-190.

Perea, D., Ubilla, M., and Piñeiro, G. 1996. First fossil record (Late Miocene) of Phrynops (P. geoffroanus complex: Chelidae) from Uruguay. Biostratigraphical and paleoenvironmental context. Copeia 2: 445-451.

Perea, D., Ubilla, M., Martinez, S., Piñeiro, G., and Verde, M. 1994. Mamíferos neógenos del Uruguay: la edad mamífero Huayqueriense en el "Mesopotamiense". Acta Geológica Leopoldensia 39: 375-389.

Perea, D., Rinderknecht, A., Ubilla, M., Bostelmann, E., and Martínez, S. 2013. Mamíferos y estratigrafía del Neógeno de Uruguay. In: D. Brandoni, and J.I. Noriega (Eds.), El Neógeno de la Mesopotamia argentina. Asociación Paleontológica Argentina, Publicación Especial 14, Buenos Aires, p. 192-206.

Porpino, K.D.O., Fernicola, J.C., and Bergqvist, L.P. 2009. A new cingulate (Mammalia: Xenarthra), Pachyarmatherium brasiliense sp. nov., from the Late Pleistocene of Northeastern Brazil. Journal of Vertebrate Paleontology 29: 881-893.

Porpino, K.D.O., Fernicola, J.C., and Bergqvist, L.P. 2010. Revisiting the intertropical Brazilian species Hoplophorus euphractus (Cingulata, 
Glyptodontoidea) and the phylogenetic affinities of Hoplophorus. Journal of Vertebrate Paleontology 30: 911-927.

Rincón, A.D., and White, R. 2007. Los Xenarthra Cingulata del Pleistoceno tardío (Lujanense) de Cerro Misión, Estado Falcón, Venezuela. Boletín de la Sociedad Venezolana de Espeleología 41: 2-12.

Rincón, A.D., Parra, G., Prevosti, F.J., Alberdi, M.T., and Bell, C.J. 2009. A preliminary assessment of the mammalian fauna from the Pliocene-Pleistocene El Breal de Orocual locality, Monaga State, Venezuela. In: B. Albright (Ed.), Papers on Geology, Vertebrate Paleontology and Biostratigraphy, in honor of Mike O. Woodburne. Bulletin of the Museum of Northern Arizona, Flagstaff, Arizona, p. 593-620.

Rinderknecht, A., Bostelmann, E., and Ubilla, M. 2011. New genus of giant Dinomyidae (Rodentia: Hystricognathi: Caviomorpha) from the late Miocene of Uruguay. Journal of Mammalogy 92: 169-178.

Scillato-Yané, G.J. 1977. Sur quelques Glyptodontidae nouveaux (Mammalia, Edentata) du Déséadien (Oligocene inférieur) de Patagonie (Argentine). Bulletin du Muséum Nacional d'Histoire Naturelle, Sciences de la Terre 64: 249-262.

Scasso, R.A., McArthur, J.M., del Río, C.J., Martínez, S., and Thirlwall, M.F. 2001. 87Sr/86Sr Late Miocene age of fossil molluscs in the "Entrerriense" of the Valdés Península (Chubut, Argentina). Journal of South American Earth Sciences 14: 319-327.

Scott, W.B. 1903-1904. Mammalia of the Santa Cruz Beds. I Edentata. In: W.B. Scott (Ed.), Reports of the Princeton University Expeditions to Patagonia, 1896-1899. E. Schweizerbart'sche Verlagshandlung (E. Nägele), Stuttgart 5: 1-364.

Solórzano A., Rincón, A.D., and McDonald, H.G. 2015. A New Mammal Assemblage from the Late Pleistocene El Breal de Orocual, Northeast of Venezuela. In: J.M. Harris, (Ed.). La Brea and beyond: The paleontology of asphalt-preserved biotas. Natural History Museum of Los Angeles County Science Series 42, Los Angeles, p. $125-150$.

Sprechmann, P., Ferrando, L.A., and Martínez, S. 2000. Estado actual de los conocimientos sobre la Formación Camacho (mioceno?-superior?), Uruguay. In: F.G. Aceñolaza, and R. Herbst (Eds.), El Neógeno de Argentina. Serie Correlación Geológica 14, INSUGEO, Tucumán p. 47-65.

Tófalo, O.R., Orgeira, M.J., Morrás, H., Vásquez, C., Sánchez, L., Pecoits, E., Aubet, N., Sánchez, G., Zech, W., and Moretti, L. 2009. Geological, pedological and paleomagnetic study of the late Cenozoic sedimentary sequence in southwestern Uruguay, South America. Quaternary International, 210: 6-17.

Ubilla, M., Perea, D., Tambussi, C., and Tonni, E.P. 1990. Primer registro fósil de Phoenicopteridae (Aves: Charadriiformes) para el Uruguay (Mio-Plioceno). Anais da Academia Brasileira de Ciências
62: 61-68.

Valerio, A.L., and Laurito, C.A. 2011. Nuevos hallazgos de Mammalia, Xenarthra (Cingulata) y confirmación del registro de Pachyarmatherium leiseyi Downing and White, 1995 en la localidad de Buenos Aires de Palmares, provincia de Alajuela, Costa Rica. Revista Geológica de América Central 44: 131-139.

Villarroel, C., and Clavijo, J. 2005. Los mamíferos fósiles y las edades de las sedimentitas continentales del Neógeno de la Costa Caribe Colombiana. Revista de la Academia Colombiana de Ciencias 29: 345-356.

Vickaryous, M.K., and Hall, B.K. 2006. Osteoderm morphology and development in the nine-banded armadillo, Dasypus novemcinctus (Mammalia, Xenarthra, Cingulata). Journal of Morphology 267: 1273-1283.

Vizcaíno, S.F., Rinderknecht, A., and Czerwonogora, A. 2003. An enigmatic Cingulata (Mammalia: Xenarthra) from the late Miocene of Uruguay. Journal of Vertebrate Paleontology 23: 981-983.

Wagler, J.G. 1830. Natürliches System der Amphibien, mit vorangehender Classification der Säugethiere und Vögel. Gotta'schen, Münich $354 \mathrm{p}$.

Wilkinson, M. 1992. Ordered versus unordered characters. Cladistics 8: 375-385.

Woodburne, M.O. 2010. The Great American Biotic Interchange: dispersals, tectonics, climate, sea level and holding pens. Journal of Mammalian Evolution 17: 245-264.

Wyss, A.R., Flynn, J.J., Norell, M.A., Swisher III, C.C., Novacek, M.J., McKenna, M.C., and Charrier, R. 1994. Paleogene mammals from the Andes of central Chile: a preliminary taxonomic, biostratigraphic and geochronologic assessment. American Museum Novitates 3098: 1-31.

Zurita, A.E., Cuadrellia, F., Tomassini, R.L., de los Reyes, M., Luna, C., and Toriño, P. 2017. On the status of "Urotherium antiquum" (Ameghino) (Xenarthra, Glyptodontidae). Comptes Rendus Palevol 16: 303-311.

doi: 10.5710/AMGH.02.12.2017.3150

Submitted: August $24^{\text {th }}, 2017$

Accepted: December $2^{\text {nd }}, 2017$

Published online: December 19th 2017 